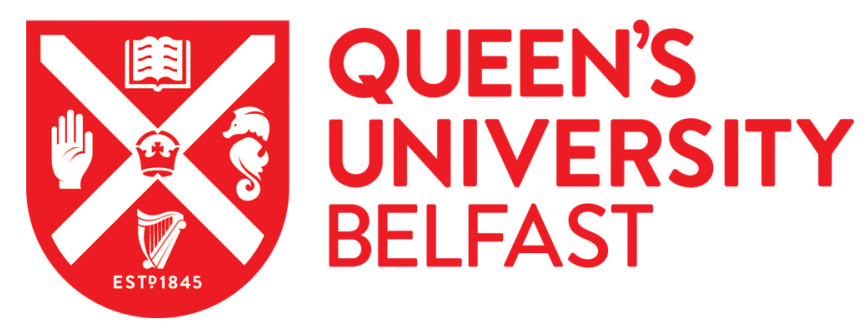

\title{
Polar aromatic periphery increases agonist potency of spirocyclic free fatty acid receptor (GPR40) agonists inspired by LY2881835
}

Krasavin, M., Lukin, A., Bagnyukova, D., Zhurilo, N., Golovanov, A., Zozulya, S., Zahanich, I., Moore, D., \& Tikhonova, I. G. (2017). Polar aromatic periphery increases agonist potency of spirocyclic free fatty acid receptor (GPR40) agonists inspired by LY2881835. European journal of medicinal chemistry, 127, 357-368. https://doi.org/10.1016/j.ejmech.2017.01.005

Published in:

European journal of medicinal chemistry

Document Version:

Peer reviewed version

Queen's University Belfast - Research Portal:

Link to publication record in Queen's University Belfast Research Portal

Publisher rights

(c) 2017 This manuscript version is made available under the CC-BY-NC-ND 4.0 license http://creativecommons.org/licenses/by-nc$\mathrm{nd} / 4.0 /$,which permits distribution and reproduction for non-commercial purposes, provided the author and source are cite

\section{General rights}

Copyright for the publications made accessible via the Queen's University Belfast Research Portal is retained by the author(s) and / or other copyright owners and it is a condition of accessing these publications that users recognise and abide by the legal requirements associated with these rights.

Take down policy

The Research Portal is Queen's institutional repository that provides access to Queen's research output. Every effort has been made to ensure that content in the Research Portal does not infringe any person's rights, or applicable UK laws. If you discover content in the Research Portal that you believe breaches copyright or violates any law, please contact openaccess@qub.ac.uk. 


\title{
Polar aromatic periphery increases agonist potency of spirocyclic free fatty acid receptor (GPR40) agonists inspired by LY2881835
}

Mikhail Krasavin, ${ }^{a,}{ }^{*}$ Alexey Lukin, ${ }^{b}$ Daria Bagnyukova, ${ }^{b}$ Nikolay Zhurilo, ${ }^{b}$ Aleksei Golovanov, ${ }^{b}$ Sergey Zozulya, ${ }^{c, d}$ Ihor Zahanich, ${ }^{c}$ Daniel Moore, ${ }^{e}$ and Irina G. Tikhonova ${ }^{e}$

a Saint Petersburg State University, Saint Petersburg, 199034 Russian Federation

${ }^{b}$ Lomonosov Institute of Fine Chemical Technologies, Moscow Technological University, 86 Vernadskogo Prospekt, Moscow, 117571 Russian Federation

${ }^{c}$ Enamine Ltd, 78 Chervonotkatska, Kyiv 02094, Ukraine

${ }^{d}$ Taras Shevchenko National University, 62 Volodymyrska, Kyiv 01033, Ukraine

e Molecular Therapeutics, School of Pharmacy, Medical Biology Centre, Queen's University Belfast, Belfast BT9 7BL, Northern Ireland, UK

* Corresponding author; phone: + 7931 3617872, fax: +7 8124286939.

E-mail address: $\underline{\text { m.krasavin@spbu.ru }}$

\begin{abstract}
A series of spirocyclic compounds inspired by Eli Lilly's phase 1 antidiabetic FFA1 receptor agonist LY2881835 was designed to include polar aromatic periphery groups and explore a possibility of building additional contacts with the target near the agonist binding site. The frontrunner compound in the series (9i) was shown to be a potent $\left(\mathrm{EC}_{50}=260 \mathrm{nM}\right)$ FFA1 agonist with excellent aqueous (PBS) solubility and good Caco-2 permeability. The observed structureactivity relationships were rationalized by a docking study. The new series significantly expands the ligand landscape for the ongoing quest for new potent and more polar FFA1 agonists as fundamentally new class of therapeutic agents against type 2 diabetes mellitus.
\end{abstract}

Keywords: Drug discovery; FFA1 agonists; antidiabetic agents; spirocyclic motifs; hydrophobic interactions; $\pi-\pi$ stacking; reductive amination.

\section{Introduction}

De-orphaning of G-protein coupled receptor GPR40 in 2003 led to its being re-named as free fatty acid receptor 1 (FFA1) due to the demonstrated involvement of medium- to long-chain endogenous fatty acids in its activation [1]. Shortly thereafter, it was shown that the endogenous ligand binding to FFA1 regulates the secretion of insulin in pancreatic $\beta$-cells and is, therefore, linked to glucose homeostasis. Interestingly, the basal expression levels of FFA1 in normal state 
are low but do become upregulated in hyperglycemic states, which makes the receptor an ideal target for therapeutic intervention. Moreover, once the glucose levels are normalized, the level of FFA1 expression goes back to normal thereby preventing hypoglycemia, even if an agonist is still in circulation [2]. Taken together, these observations unquestionably validated FFA1 as a therapeutic target of great promise in delivering new treatment for type 2 diabetes mellitus (T2DM) which would be devoid of adverse reactions of the drugs currently in clinical use. The interest toward this target from the industry and academic research teams was clearly evidenced by the discovery of a number of synthetic agonists over the decade following FFA1 validation as an antidiabetic target [3]. Unfortunately, the field was adversely affected by the discontinuation of the phase III clinical trials of Takeda's fasiglifam (TAK-875) in December 2013 due to idiosynchratic liver toxicity observed within an extended patient population, which caused a sharp drop in the amount of effort worldwide to bring new FFA1 agonists as drugs to the market [4]. At the time of preparing this manuscript, only two phase I clinical studies (Piramal's compound P11187 of undisclosed structure and SHR0534 or fusiglifam from Hengrui) were underway [5]. This is rather unfortunate as in fact, the proof of principle for the new therapeutic approach was clearly obtained in the course of TAK-875 clinical research [6]. Considering the fact that FFA1 is mainly expressed in the pancreas and in the brain [7], the hepatotoxicity of TAK-875 is likely related to the specific molecular structure of this (rather lipophilic [8]) molecule and not to the action at the receptor. In fact, much of the research in the last 3 years (i. e. after the discontinuation of TAK-875) has been focused on the discovery and development of more polar, less lipophilic FFA1 agonists [9].

Figure 1. Polar-appendage (1-2) and scaffold-hopping (3-4) approaches toward less lipophilic FFA1 agonists.
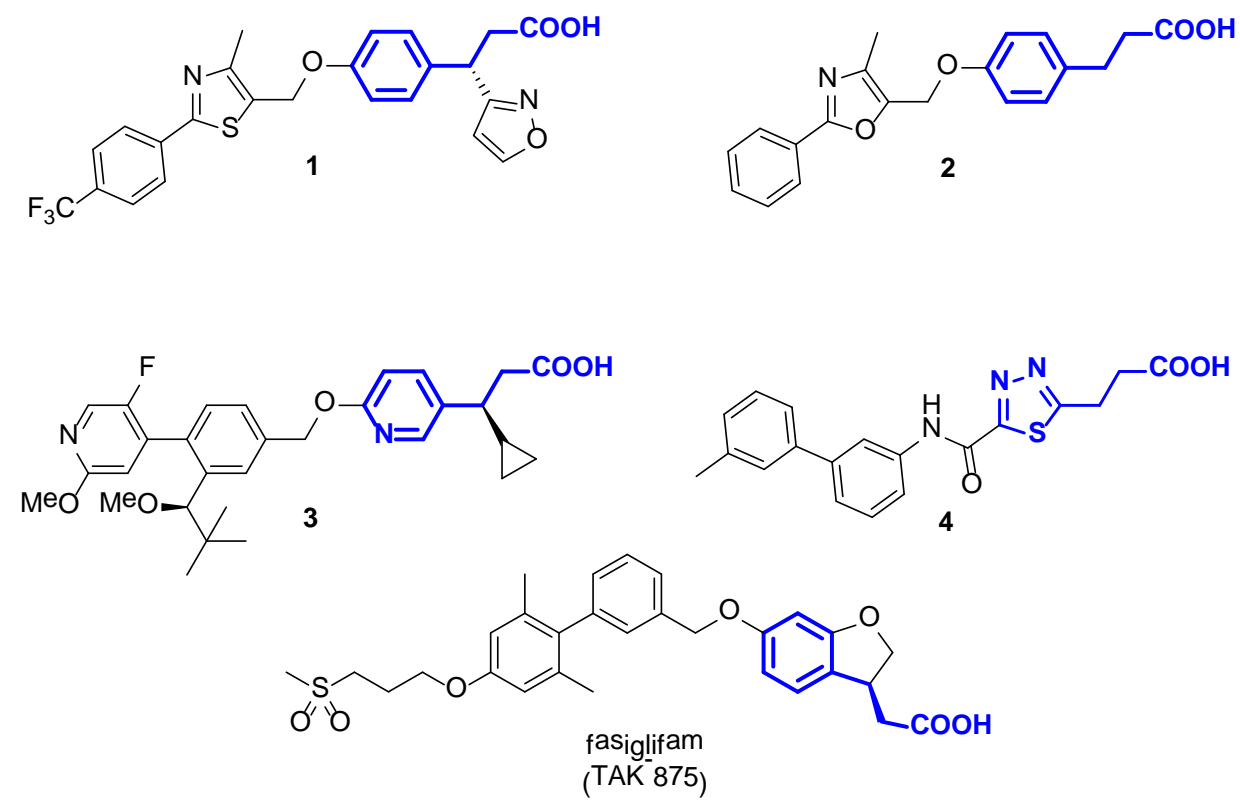
Aiming at more polar FFA1 agonists could be considered a 'tug of war' as lipophilicity is a known driver of ligand potency for the free fatty acid receptors [10]. A sensible approach toward this goal typically includes fine-tuning of either the polar appendage groups around the 3-phenypropionic acid pharmacophore (as in, for example, 1 [11] and 2 [12]) or replacing this core with more polar heterocyclic congeners, i.e. applying the scaffold-hopping approach exemplified by $\mathbf{3}$ [13] and $\mathbf{4}$ [14] (Figure 1). Ideally, this is done in conjunction with attempts to create new specific interactions with the target that could compensate for the affinity loss due to the decreased lipophilicity [12, 14].

Figure 2. LY2881835 and the rational design of the earlier reported (6-8) and newly developed (9) FFA1 agonists.
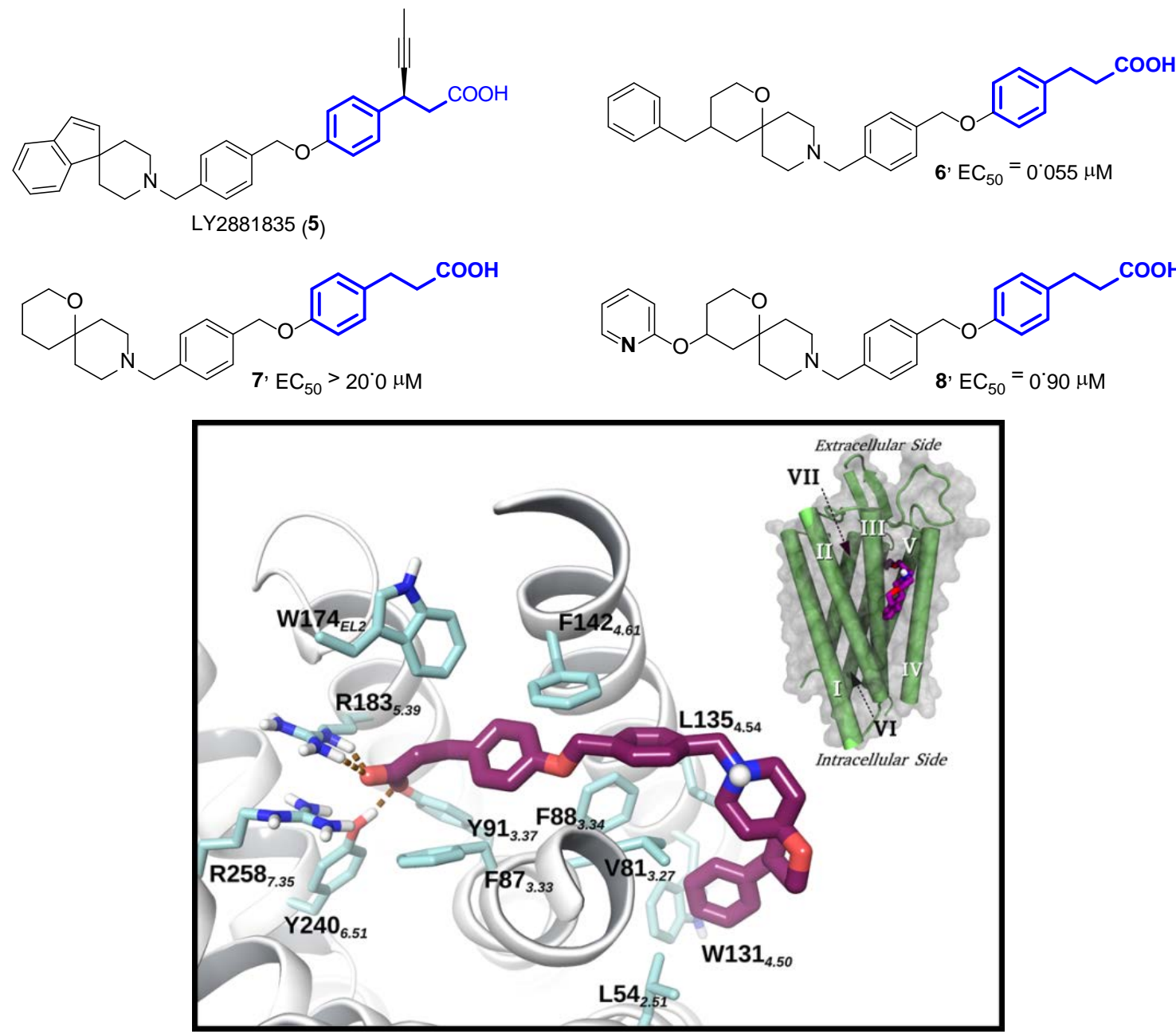

$\underset{p o l a r}{\text { aromatics }}$
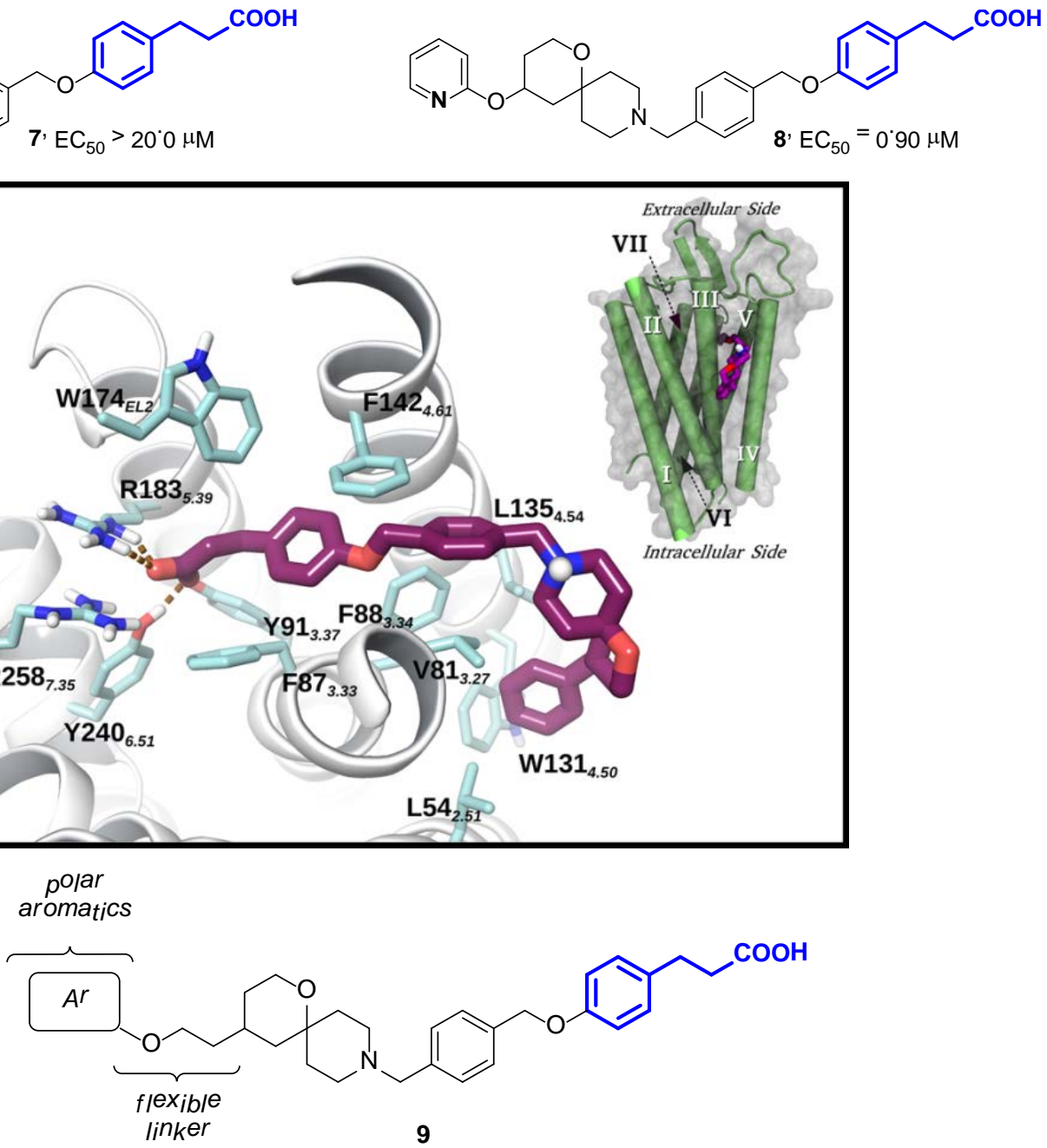
Recently, we became intrigued by the structure of LY2881835 (5), Eli Lilly's advanced FFA1 agonist, which progressed through phase I clinical trials [3]. In addition to 3-phenylpropanoic acid pharmacophoric core, the compound contains a spirocyclic piperidine moiety with a basic amine nitrogen atom, which constitutes an unusual feature for the FFA1 agonist landscape [4]. More importantly, it extends the range of structural motifs that can be explored as periphery 'decoration' of potential FFA1 agonists in the ongoing quest for more polar compounds (as the tertiary amine nitrogen will most likely be protonated at physiological $\mathrm{pH}$ ). In this context, we saw a great opportunity to incorporate a greater diversity of spirocyclic motifs (amenable by our recently reported Prins cyclization protocol [15]) into a new series of FFA1 agonists inspired by LY2881835. Spirocyclic moieties in general are considered privileged structures for GPCR ligand design due to their pronounced three-dimensional character, better complementarity to the protein target of interest and lower off-target effects [16]. This prompted us to develop a series of spirocyclic compounds which delivered lead structure 6 [17]. It has a potency of $55 \mathrm{nM}$ which is in sharp contrast with inactive compound 7 where the 1-oxa-9-azaspiro[5.5] undecane periphery is unsubstituted. More recently, we have also demonstrated that incorporation of significantly more polar isosteres (as in compound 8, which is somewhat less potent with an $\mathrm{EC}_{50} 900 \mathrm{nM}$ ) was also possible and is not detrimental to compound's potency [18]. For compound 6, we demonstrated that the presence of the benzyl substituent (which is absent in inactive compound 7) provides more than just a lipophilicity-driven potency increase. The benzyl group appeared to define a specific orientation of the spirocyclic moiety in $\mathbf{6}$ (pointing toward the intracellular side of the receptor) reinforced by a network of favorable hydrophobic interactions with L542.51, L1354.54 and V813.27 as well as a $\pi$-stacking interaction with W1314.50 [17]. Such a consideration prompted us to investigate a series of compounds $\mathbf{9}$ in which a polar heteroaromatic moiety (as that in compound 8) would be attached to the crucial 1-oxa-9-azaspiro[5.5] undecane system via a more flexible, 3atom linker to enable the compound to assume a more energetically favored conformation and accommodate the azine periphery within the nearby binding pocket (Figure 2). Herein, we disclose our recent results in this regard.

\section{Results and discussion}

\subsection{Chemistry}

Retrosynthetically, the target compounds could be disconnected to building blocks $\mathbf{1 0}$ and 13, gram-scale synthesis of which had been reported earlier [17, 19] (Figure 3).

Figure 3. Retrosynthetic analysis of spirocyclic FFA1 agonists $\mathbf{9}$ investigated in this work. 


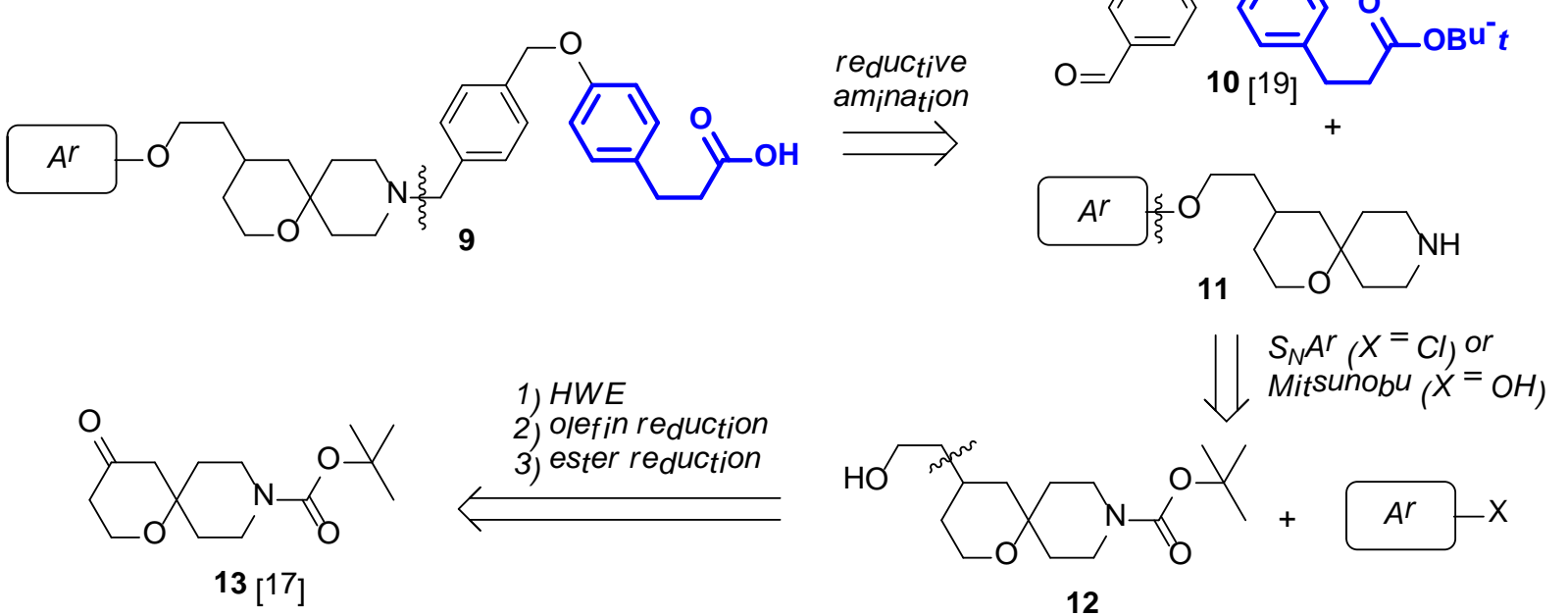

This synthetic strategy was realized as shown in Scheme 1. Key spirocyclic ketone $\mathbf{1 3}$ was prepared on multigram scale via the Prins cyclization of 1-benzyl-4-piperidone and homoallyl alcohol followed by the protecting group exchange [15] and secondary alcohol oxidation with PDC [17].

Scheme 1. Synthesis of compound 9a-m investigated as FFA1 agonists in this work.

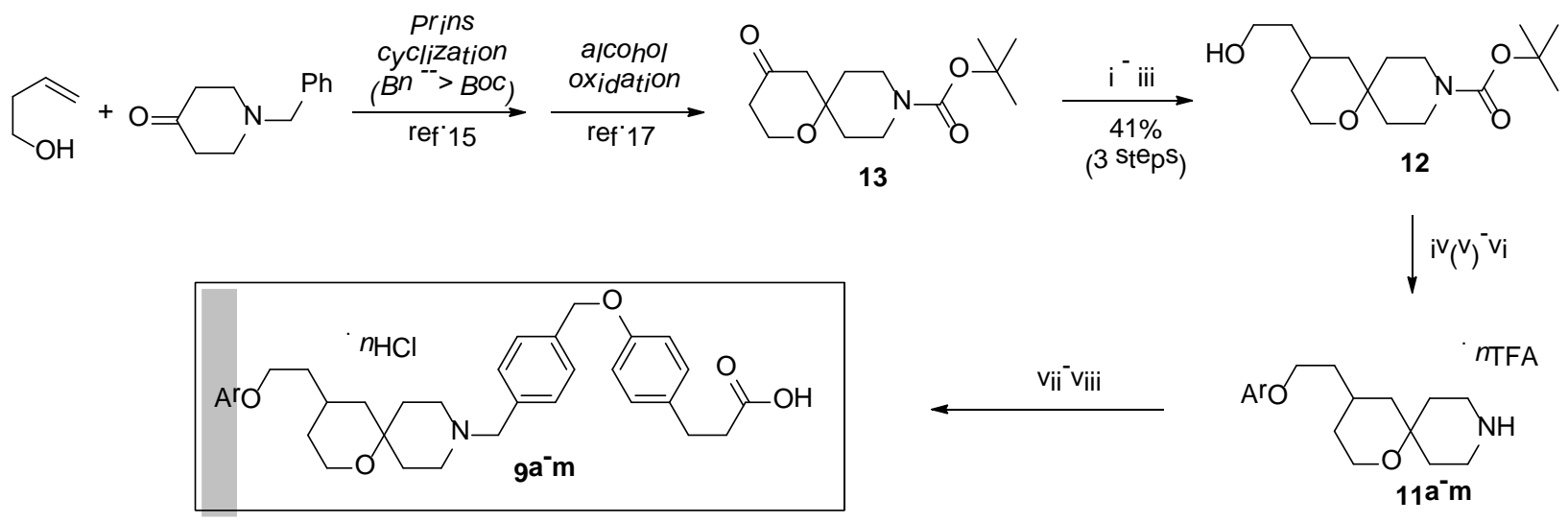

Reagents and conditions: (i) EtOOCCH${ }_{2} \mathrm{P}(\mathrm{O})(\mathrm{OEt})_{2}, \mathrm{NaH}$, THF, $0{ }^{\circ} \mathrm{C} \rightarrow \mathrm{rt}, 18 \mathrm{~h}$; (ii) $\mathrm{HCOONH}_{4}$, 10\% Pd-C, EtOH, reflux, 12 h; (iii) $\mathrm{LiAlH}_{4}$, THF, rt, 2h; (iv) NaH, ArCl, DMF, $0{ }^{\circ} \mathrm{C} \rightarrow$ rt, 16 h (11b-l); (v) ArOH, DIAD, THF, $0{ }^{\circ} \mathrm{C} \rightarrow$ rt, 16 h (11a, 11m); (vi) TFA, $\mathrm{CH}_{2} \mathrm{Cl}_{2}, 0{ }^{\circ} \mathrm{C}$, 6h; (vii) 10, $\mathrm{Et}_{3} \mathrm{~N}, \mathrm{NaBH}(\mathrm{OAc})_{3}, \mathrm{CH}_{2} \mathrm{Cl}_{2}, 12$ h, rt; (viii) $4 \mathrm{M} \mathrm{HCl}, 1,4$-dioxane, rt, $6 \mathrm{~h}$.

The subsequent 2-hydroxyethyl side chain installation was achieved in three chemical operations including the Horner-Wadsworth-Emmons olefination reaction, double bond hydrogenation over a palladium catalyst using ammonium formate as a hydrogen source, and the LAH reduction of the ester functionality to the respective primary alcohol 12. A reasonable total chemical yield of 41\% was achieved for the three synthetic steps. Having installed the requisite 2-hydroxyethyl side 
chain, we proceeded to decorate it with a range of (hetero)aromatic groups. Most of these could

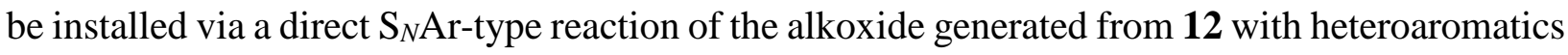
containing labile chloro-substituent. Alternatively, respective hydroxyaromatic building block was coupled to 12 under the standard Mitsunobu conditions. Removal of the Boc protecting group with TFA furnished spirocyclic piperidine building blocks 11a-m which were alkylated with aldehyde 10 in reductive conditions (STAB) and, without purification, the resulting tert-butyl ester precursors were converted, using $4 \mathrm{M} \mathrm{HCl}$ in 1.4-dioxane, to free carboxylic acids 9a-m, which were isolated as hydrochloride salts (Scheme 1).

\subsection{Biological activity}

Potential FFA1 agonists 9a-m synthesized as described above, were tested for their ability to activate FFA1 using calcium flux assay employing Chinese hamster ovary (CHO) cells engineered to stably express human FFA1. All compounds were tested in dose-response mode in order to calculate the respective $\mathrm{EC}_{50}$ values and determine \% of maximum efficacy achieved for active compounds relative to commercially available reference FFA1 agonist GW9508 [20].

From the data obtained on activation of FFA1 receptor by compounds 9a-m (Table 1), it becomes evident that the idea of presenting polar aromatic periphery on an extended, three-atom linker resulted in low-micromolar potency for the majority of compounds (while the low potency of $\mathbf{9 b}$ is somewhat puzzling). Starting from the best compound in the azine-decorated series $\left(\mathbf{8}, \mathrm{EC}_{50}=\right.$ $0.9 \mu \mathrm{M}$, vide supra) we reported earlier [18], the goal in present study was to optimize the same or similar polar azine (or other aromatic) periphery to be accommodated in the nearby binding pocket. The bioactivity data in Table 1 essentially reflect the gradual fine-tuning of the potency and the efficacy of compounds 9a-m until the best fit to the binding pocket manifests itself in compound 9i, which we regard as unquestionable frontrunner in this series. Compound $9 \mathbf{i}$ not only displays a pronounced restoration of the receptor affinity by the side chain present in it compared to its unsubstituted (inactive) counterpart 7, it also shows a significant improvement over its double homolog 8. Considering the fact that compounds $\mathbf{9 h}$ and $\mathbf{9 i}$ are mere positional isomers and, therefore, have an identical cLogP of 5.84 [21], the >4-fold difference in potency is likely attributable to the better accommodation of $\mathbf{9 i}$ by FFA1 (vide infra). 
Table 1. FFA1 agonists 9a-m studied in this work.

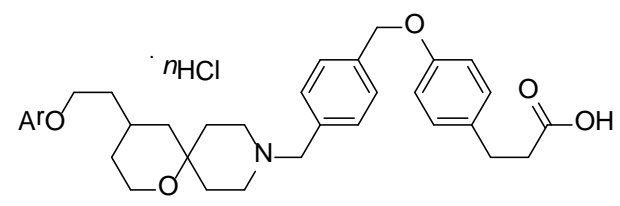

\begin{tabular}{|c|c|c|c|c|}
\hline Compound & $\mathrm{Ar}$ & $n$ & $\mathrm{FFA}_{1} \mathrm{EC}_{50} \pm \mathrm{SD}, \mu \mathrm{M}^{a}$ & $\%$ efficacy $^{b}$ \\
\hline 9a & & 1 & $2.06 \pm 0.34$ & 55.0 \\
\hline $9 b$ & & 2 & $33.5 \pm 1.54$ & 79.2 \\
\hline 9c & & 2 & $2.36 \pm 0.61$ & 83.4 \\
\hline 9d & & 2 & $1.14 \pm 0.15$ & 80.2 \\
\hline $9 e$ & & 2 & $1.26 \pm 0.47$ & 78.4 \\
\hline 9f & & 2 & $1.48 \pm 0.28$ & 83.5 \\
\hline $9 \mathrm{~g}$ & & 2 & $1.21 \pm 0.52$ & 60.5 \\
\hline $9 h$ & & 2 & $1.11 \pm 0.12$ & 110.3 \\
\hline $9 \mathbf{i}$ & & 2 & $0.26 \pm 0.07$ & 100.3 \\
\hline $9 \mathbf{j}$ & & 2 & $3.87 \pm 1.01$ & 54.5 \\
\hline $9 \mathbf{k}$ & & 2 & $1.27 \pm 0.44$ & 104.9 \\
\hline 91 & & 2 & $6.10 \pm 1.23$ & 48.5 \\
\hline $9 m$ & & 2 & $2.56 \pm 0.33$ & 61.7 \\
\hline
\end{tabular}

${ }^{a}$ Each value is an average of $n=4$.

${ }^{b}$ Relative to GW9508 [20] (5 $\left.\mu \mathrm{M}\right)$.

We further profiled lead compound 9i for selectivity against other free fatty acid receptors (FFA3/GPR41, FFA2/GPR43 and FFA4/GPR120). FFA2 and FFA3 bind short-chain fatty acids preferentially, while FFA1 and FFA4 have a higher affinity to medium-and long chain fatty acids 
[22-23]. Compound 9i showed no activation of any of these receptors (except for FFA1) at concentrations as high as $10 \mu \mathrm{M}$ (Table 2).

Table 2. Selectivity profile of compound $\mathbf{9 i}{ }^{a}$

\begin{tabular}{lc}
\hline & $\mathrm{EC}_{50}(\mu \mathrm{M})$ \\
\hline Human FFA1/GPR40 & 0.26 \\
Human FFA3/GPR41 & $>10$ \\
Human FFA2/GPR43 & $>10$ \\
Human FFA4/GPR120 & $>10$ \\
\hline
\end{tabular}

${ }^{a}$ Each value is an average of $n=4$ in the presence of $0.1 \%$ BSA.

We also obtained the preliminary ADME profile of $\mathbf{9 i}$ by determining its Caco- 1 permeability, stability toward incubation with mouse liver microsomes (MLM) and solubility in aqueous phosphate buffer solution (Table 3). Unsurprisingly, the polar substituted pyridine periphery led to significant aqueous solubility and the compound had a good Caco-2 permeability. The metabolic stability was somewhat low which was already reported for compounds with a similar molecular scaffold [17]. The rapid MLM clearance can indeed be attributed to the presence of two heteroatom-substituted benzylic positions in $\mathbf{9 i}$ and/or $\beta$-unsubstituted which is a known weak spot of FFA1 agonists, prone to metabolic oxidation [4].

Table 3. ADME profile of compound $\mathbf{9 i}$.

\begin{tabular}{|c|c|c|}
\hline Aqueous solubility (PBS, $\mathrm{pH} 7.4)^{a}(\mu \mathrm{M})$ & & 228 \\
\hline Metabolic stability & $\mathrm{T}_{1 / 2}, \min$ & 22.9 \\
\hline (mouse liver microsomes) & CLint, $\mu \mathrm{L} / \mathrm{min} / \mathrm{mg}$ & 72.8 \\
\hline A-B permeability $\left(\text { Caco- } 2, \mathrm{~cm} \cdot \mathrm{s}^{-1}\right)^{b}\left(\cdot 10^{-6}\right)$ & & 7.3 \\
\hline
\end{tabular}

\subsection{Docking studies}

In order to rationalize the dramatic difference in potency between unsubstituted spirocyclic compound 7 reported earlier [17] and frontrunner compound 9i identified in this study, which differ only in the presence of 2-[(6-methylpyrid-2-yl)oxy]ethyl side chain in the 1-oxa-9- 
azaspiro[5.5] undecane portion of $\mathbf{9 i}$, we docked these compounds in the FFA1 binding site (Figure 4).

Figure 4. Docked poses of compounds 7 and $\mathbf{9 i}$ at FFA1. (A) Overlay of $\mathbf{7}$ (green) and 9i (orange) in the FFA1 binding site. (B) Hydrophobic interactions of the 2-[(6-methylpyrid-2-yl)oxy]ethyl side chain. Protein-ligand interactions are only visualized for compound $9 i$. Hydrogen bonds, $\pi-\pi$ and hydrophobic interactions are in brown, blue and yellow dashed-lines, respectively. Each transmembrane helix is labeled in red roman numerals. Residues are labeled with their position followed by the Ballesteros and Weinstein numbering [24] in subscript. EL2 refers to the extracellular loop 2.

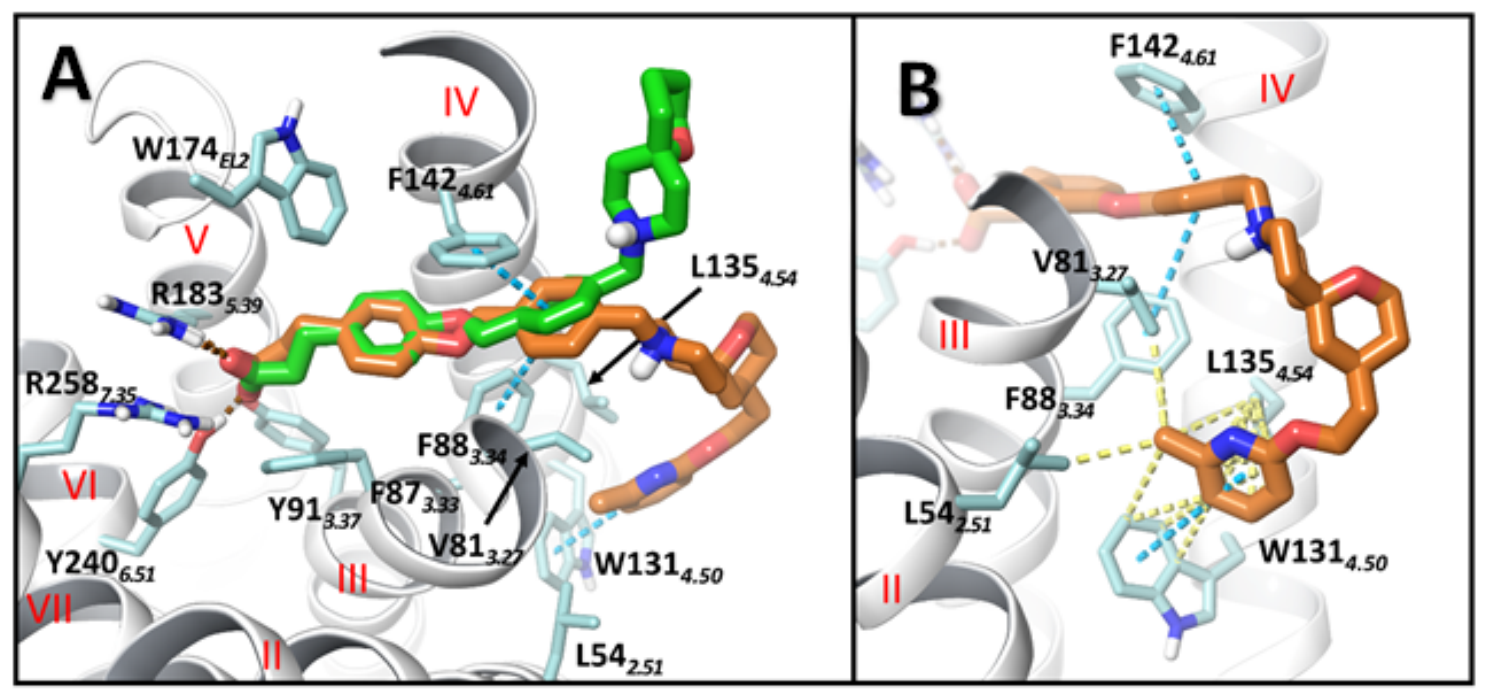

Both compounds assume similar positions within the biding site (Figure 4A) forming critical

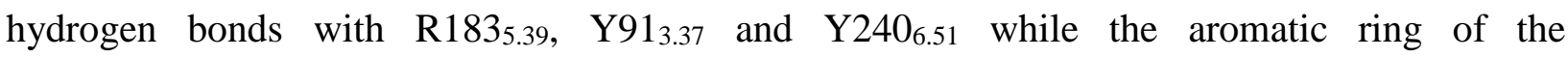
phenylpropanoic acid moiety is in close proximity to F88 ${ }_{3.34}, \mathrm{~F} 142_{4.61}$, W174 $\mathrm{EL2}$ and F873.33. The docking results clearly demonstrate that the 2-[(6-methylpyrid-2-yl)oxy]ethyl side chain of 9i is within the hydrophobic cavity encompassed by L542.51, V81 $3.27, \mathrm{~W} 131_{4.50}$ and L1354.54 (Figure 4B). Apparently, the attachment of the pyridyl moiety to the spirocyclic fragment of 7 with a flexible, three-atom linker allows an optimal positioning of the periphery heterocycle within this cavity with negligible strain on the ligand. It is clearly visible that the 6-methyl substituent is buried within the cavity, which facilitates the formation of the $\pi-\pi$ stacking contact between the pyridine ring and $\mathrm{W} 131_{4.50}$. The latter appears to be vital for stabilizing the bound conformation of the ligand and its strength depends on the substituents in the aromatic rings involved in the interaction [25]. This observation could, for instance, help rationalize the significantly decreased potency of compound $\mathbf{9 b}\left(\mathrm{EC}_{50}=33.5 \mu \mathrm{M}\right)$, which is the only one in the series that has a strongly electron-withdrawing substituent in the azine ring. 


\section{Conclusions}

We have successfully explored the possibility of decorating the 1-oxa-9-azaspiro[5.5]undecane portion of inactive compound 7 (reported earlier as inspired by LY2881835) with polar (hetero)aromatic heterocycles attached via a flexible 3-atom linker to enable the optimal accommodation of these residues within the hydrophobic pocket identified earlier near the binding site of FFA1 agonists. One of the resulting compounds (9i) displayed a high potency and efficacy as FFA1 agonist and demonstrated excellent aqueous solubility, Caco-2 permeability and somewhat rapid metabolism in the presence of human liver microsomes. The compound clearly provides a strong proof-of-principle for the design approach taken toward new antidiabetic agents acting via FFA1 activation that includes the use of polar periphery residues. These findings significantly expand the FFA1 agonist chemistry space for the ongoing quest for new, more polar agents that would have a lesser chance of displaying idiosyncratic hepatotoxicity.

\section{Experimental protocols}

All reactions were conducted in oven-dried glassware in atmosphere of nitrogen. Melting points were measured with a Buchi B-520 melting point apparatus and were not corrected. Analytical thin-layer chromatography was carried out on Silufol UV-254 silica gel plates using appropriate mixtures of ethyl acetate and hexane. Compounds were visualized with short-wavelength UV light. ${ }^{1} \mathrm{H}$ NMR and ${ }^{13} \mathrm{C}$ NMR spectra were recorded on Bruker MSL-300 spectrometers in DMSO-D6$d_{6}$ using TMS as an internal standard. Mass spectra were recorded using Shimadzu LCMS-2020 system with electron-spray (ESI) ionization. All and reagents and solvents were obtained from commercial sources and used without purification.

All mass-spectroscopic measurements required for determination of ADME properties were performed using Shimadzu VP HPLC system including vacuum degasser, gradient pumps, reverse phase HPLC column, column oven and autosampler. The HPLC system was coupled with tandem mass spectrometer API 3000 (PE Sciex). The TurboIonSpray ion source was used in both positive and negative ion modes. Acquisition and analysis of the data were performed using Analyst 1.5.2 software (PE Sciex).

\subsection{Synthesis}

\subsection{1 tert-Butyl 4-(2-hydroxyethyl)-1-oxa-90-azaspiro[5.5] undecane-9-carboxylate (12).}

To a $0{ }^{\circ} \mathrm{C}$, vigorously stirred suspension of $\mathrm{NaH}$ (6.54 g, $163 \mathrm{mmol}$, 60\% dispersion in mineral oil) in THF (300 mL) thriethylphosphonoacetate (45 g, $200 \mathrm{mmol})$ was added dropwise under argon. The stirring continued at that temperature for $1 \mathrm{~h}$, whereupon a solution of $\mathbf{1 3}$ (40 g, 149 
mmol), prepared as described earlier [17], in THF (100 mL) was added. The reaction mixture was allowed to reach r. t. and was stirred at that temperature for $18 \mathrm{~h}$. The reaction mixture was poured into water (500 mL) and the aqueous phase was extracted with ethyl acetate ( 3 x $200 \mathrm{~mL}$ ). The combined organic extracts wer washed with $3 \%$ aqueous citric acid, $5 \%$ aqueous $\mathrm{NaHCO}_{3}$, brine, dried over anhydrous $\mathrm{Na}_{2} \mathrm{SO}_{4}$, filtered and concentrated in vacuo. The residue was fractionated on silica gel using $0 \rightarrow 5 \%$ ethyl acetate in hexanes as eluent. The fractions containing the olefination product (according to LC MS analysis) were pooled and concentrated to dryness (yielding $32.7 \mathrm{~g}$ of the material). The residue (10.9 g) was dissolved in EtOH (200 mL), $\mathrm{HCOONH}_{4}(2.8 \mathrm{~g}, 0.44$ $\mathrm{mmol}$ ) and $10 \% \mathrm{Pd}$ on carbon (300 mg) were added and the resulting mixture was heated at reflux for $12 \mathrm{~h}$. The mixture was cooled to r. t. and filtered through a plug of Celite (subsequently washing the latter with EtOH). The combined filtrate and washings were concentrated to dryness. The residue was partitioned between water $(150 \mathrm{~mL})$ and ethyl acetate $(150 \mathrm{~mL})$. The organic layer was separated and the aqueous layer was additionally extracted with ethyl acetate (2 x $150 \mathrm{~mL})$. The combined organic extracts were washed with 3\% aqueous citric acid, $5 \%$ aqueous $\mathrm{NaHCO}_{3}$ and brine, dried over anhydrous $\mathrm{Na}_{2} \mathrm{SO}_{4}$, filtered and concentrated in vacuo. The residue was dissolved in dry THF (200 mL) and to this solution, LiAlH4 (1.1 g, $29.3 \mathrm{mmol})$ was added in small portions on vigorous stirring. The stirring continued at room temperature for $2 \mathrm{~h}$ whereupon water $(1.1 \mathrm{~mL}), 15 \%$ aqueous $\mathrm{NaOH}(1.1 \mathrm{~mL})$ and water $(3.3 \mathrm{~mL})$ were sequentially added. The residue formed was filtered off, washed with THF ( 2 x $50 \mathrm{~mL})$ and the combined filtrate and washings were concentrated in vacuo to provide the analytically pure title compound.

Amorphous solid, yield 18,266 mg (41\% over 3 steps); ${ }^{1} \mathrm{H}$ NMR (300 MHz, $\left.\mathrm{CDCl}_{3}\right) \delta 3.77-3.63$ (m, 5H), 3.56 (td, $J=12.3,2.2 \mathrm{~Hz}, 1 \mathrm{H}), 3.23-3.12$ (m, 1H), 3.06 - 2.94 (m, 1H), 2.26 (s, 1H), $2.19-2.10$ (m, 1H), $1.94-1.78(\mathrm{~m}, 1 \mathrm{H}), 1.66$ - 1.52 (m, 2H), 1.51 - 1.45 (m, 3H), 1.43 (s, 9H), 1.32 - 0.99 (m, 4H); ${ }^{13} \mathrm{C}$ NMR (75 MHz, CDCl) $\delta 155.0,79.3,70.4,60.7,59.8,42.9,39.9,39.8$,

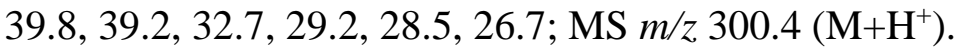

\subsubsection{General procedure 1 (GP1): preparation of 1-oxa-9-azaspiro[5.5] undecanes 11b-I}

To $0{ }^{\circ} \mathrm{C}$ suspension of $\mathrm{NaH}$ (60\% suspension in mineral oil, $\left.220 \mathrm{mg}, 5.6 \mathrm{mmol}\right)$ in dry DMF (100 $\mathrm{mL})$ a solution of $\mathbf{1 3}(1.0 \mathrm{~g}, 3.3 \mathrm{mmol})$ in dry DMF $(20 \mathrm{~mL})$ was added. The resulting mixture was stirred at $0{ }^{\circ} \mathrm{C}$ for $30 \mathrm{~min}$ and then treated with a solution of the respective 2-chloroazine (5.0 mmol) in dry DMF (10 mL). The mixture was allowed to warm up to r. t. and stirred at that temperature for $16 \mathrm{~h}$. It was poured into water $(200 \mathrm{~mL})$ and the resulting slurry was extracted with ethyl acetate ( $3 \times 200 \mathrm{~mL}$ ). The combined organic extracts were washed with 5\% aqueous citric acid, 5\% aqueous $\mathrm{NaHCO}_{3}$, brine and dried over anhydrous $\mathrm{Na}_{2} \mathrm{SO}_{4}$. The solid drying agent was filtered off and the filtrate was concentrated in vacuo. The residue was dissolved in $\mathrm{CH}_{2} \mathrm{Cl}_{2}$ 
(10 mL), the solution was cooled to $0{ }^{\circ} \mathrm{C}$ and TFA (3 mL) was added. The mixture thus obtained was stirred at $0{ }^{\circ} \mathrm{C}$ for $6 \mathrm{~h}$ and then concentrated in vacuo to dryness to provide, after crystallization from isopropyl alcohol, the target compounds as ditrifluoroacetate salts.

4.1.3 4-(25-(Trifluoromethyl)pyridin-2-yl]oxy\}ethyl)-1-oxa-9-azaspiro[5.5]undecane ditrifluoroacetate $\mathbf{( 1 1 b )}$

Viscous oil, yield 67\%; ${ }^{1} \mathrm{H}$ NMR (300 MHz, DMSO-d $\left.{ }_{6}\right) \delta 8.56-8.53(\mathrm{~m}, 1 \mathrm{H}), 8.33(\mathrm{~s}, 1 \mathrm{H}), 8.03$ (dd, $\left.J_{1}=2.61 \mathrm{~Hz}, J_{2}=8.80 \mathrm{~Hz}, 1 \mathrm{H}\right), 6.97(\mathrm{~d}, J=8.74 \mathrm{~Hz}, 1 \mathrm{H}), 4.37(\mathrm{t}, J=6.65 \mathrm{~Hz}, 2 \mathrm{H}), 3.68-$ 3.62 (m, 1H), 3.52 - 3.44 (m, 1H), 3.11 - 2.99 (m, 3H), $2.89-2.78$ (m, 1H), $2.36-2.28$ (m, 1H), $1.93-1.80$ (m, 1H), $1.72-1.52$ (m, 6H), $1.46-1.35$ (m, 1H), $1.19-0.97$ (m, 2H); ${ }^{13} \mathrm{C}$ NMR (75 MHz, DMSO-d $d_{6} \delta 165.7,144.9(\mathrm{q}, J=4.5 \mathrm{~Hz}), 136.4$ (q, $\left.J=3.1 \mathrm{~Hz}\right), 124.2$ (q, $\left.J=271.1 \mathrm{~Hz}\right)$, $118.7(\mathrm{q}, J=32.5 \mathrm{~Hz}), 111.4,68.2,63.9,60.1,41.8,35.4,32.0,26.5,25.6$; MS m/z $345.5\left(\mathrm{M}+\mathrm{H}^{+}\right)$.

4.1.4 4-[2-(Quinolin-2-yloxy)ethyl]-1-oxa-9-azaspiro[5.5] undecane ditrifluoroacetate (11c)

Viscous oil, yield 24\%; ${ }^{1} \mathrm{H}$ NMR (300 MHz, DMSO-d $\left.d_{6}\right) \delta 8.53(\mathrm{~s}, 1 \mathrm{H}), 8.22$ (d, $J=8.86 \mathrm{~Hz}, 1 \mathrm{H}$ ), 7.87 (d, $J=7.93 \mathrm{~Hz}, 1 \mathrm{H}), 7.75$ (d, $J=8.29 \mathrm{~Hz}, 1 \mathrm{H}), 7.70-7.61$ (m, 1H), $7.46-7.39$ (m, 1H), 6.99 (d, $J=8.84 \mathrm{~Hz}, 1 \mathrm{H}), 4.46$ (t, $J=6.54 \mathrm{~Hz}, 2 \mathrm{H}), 3.71-3.63(\mathrm{~m}, 1 \mathrm{H}), 3.56-3.42(\mathrm{~m}, 1 \mathrm{H}), 3.14$ - 2.77 (m, 4H), $2.39-2.30$ (m, 1H), $2.00-1.84$ (m, 1H), $1.76-1.36$ (m, 7H), $1.24-1.01$ (m, $2 \mathrm{H}) ;{ }^{13} \mathrm{C}$ NMR (75 MHz, DMSO-d $\left.)\right) \delta 161.6,145.9,139.3,129.8,127.8,126.6,124.8,124.1$,

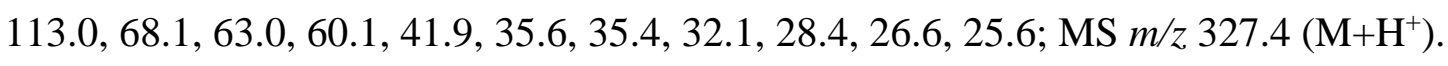

4.1.5 4-\{2-[(3,6-Dimethylpyrazin-2-yl)oxy]ethyl\}-1-oxa-9-azaspiro[5.5] undecane ditrifluoroacetate (11d)

Viscous oil, yield 45\%; ${ }^{1} \mathrm{H}$ NMR (300 MHz, DMSO-d 6 ) $\delta 8.55$ (s, 1H), 7.90 (s, 1H), 4.33 (t, $J=$ $6.41 \mathrm{~Hz}, 2 \mathrm{H}), 3.73-3.63$ (m, 1H), $3.56-3.44$ (m, 1H), 3.13 - 2.78 (m, 4H), $2.36-2.29$ (m, 7H), $1.96-1.81$ (m, 1H), 1.72 - 1.55 (m, 6H), 1.47 - 1.35 (m, 1H), 1.21 - 1.00 (m, 2H); ${ }^{13} \mathrm{C}$ NMR (75 MHz, DMSO- $\left.d_{6}\right) \delta 157.1,147.5,140.1,134.0,68.2,63.2,60.2,41.8,35.4,32.2,26.7,25.5,20.3$, 18.4; MS m/z $306.3\left(\mathrm{M}+\mathrm{H}^{+}\right)$.

4.1.6

4-[2-(6,7-Dihydro-5H-cyclopenta[d]pyrimidin-4-yloxy)ethyl]-1-oxa-9azaspiro[5.5] undecane ditrifluoroacetate (11e)

Viscous oil, yield 45\%; ${ }^{1} \mathrm{H}$ NMR (300 MHz, DMSO-d 6 ) $\delta 8.73$ (s, $\left.1 \mathrm{H}\right), 8.46$ (d, $J=46.70 \mathrm{~Hz}$, 2H), 4.48 (t, $J=6.46 \mathrm{~Hz}, 2 \mathrm{H}), 3.67$ (dd, $J=11.75,4.34 \mathrm{~Hz}, 1 \mathrm{H}), 3.49$ (t, $J=11.53 \mathrm{~Hz}, 1 \mathrm{H}), 3.09$ -2.85 (m, 6H), 2.80 (t, $J=7.44$ Hz, 2H), 2.33 (d, $J=14.23$ Hz, 1H), $2.15-2.02$ (m, 2H), 1.84 (d, 
$J=3.34 \mathrm{~Hz}, 1 \mathrm{H}), 1.71-1.11(\mathrm{~m}, 9 \mathrm{H}) ;{ }^{13} \mathrm{C}$ NMR (75 MHz, DMSO-d 6 ) $\delta$ 171.8, 166.0, 155.1, 120.7, 68.1, 64.5, 60.1, 41.7, 35.4, 35.2, 32.8, 32.1, 26.6, 26.3, 25.5, 21.3; MS m/z 318.3 $\left(\mathrm{M}^{+} \mathrm{H}^{+}\right)$.

4.1.7 4-[2-(6,7-Dihydro-5H-cyclopenta[d]pyrimidin-4-yloxy)ethyl]-1-oxa-9azaspiro[5.5] undecane ditrifluoroacetate (11f)

Viscous oil, yield 24\%; ${ }^{1} \mathrm{H}$ NMR (300 MHz, DMSO- $d_{6}$ ) $\delta 8.47$ (d, $J=49.34 \mathrm{~Hz}, 2 \mathrm{H}$ ), 8.28 (s, 1H), $8.20-8.18(\mathrm{~m}, 2 \mathrm{H}), 4.34$ (t, $J=6.59 \mathrm{~Hz}, 2 \mathrm{H}), 3.67$ (dd, $J=11.69,4.52 \mathrm{~Hz}, 1 \mathrm{H}), 3.49(\mathrm{t}, J=$ $11.49 \mathrm{~Hz}, 1 \mathrm{H}), 3.12$ - 2.77 (m, 4H), 2.33 (d, $J=14.60 \mathrm{~Hz}, 1 \mathrm{H}), 1.86$ (d, $J=3.65 \mathrm{~Hz}, 1 \mathrm{H}), 1.69$ 1.35 (m, 7H), 1.32 - 0.97 (m, 2H); ${ }^{13} \mathrm{C}$ NMR (75 MHz, DMSO-d 6 ) $\delta 159.8,140.8,136.7,135.37$, 68.1, 63.4, 60.1, 41.8, 35.4, 35.3, 32.0, 26.5, 25.6; MS m/z 278.5 (M+H').

4.1.8 4-\{2-[(2-Cyclopropyl-6,7-dihydro-5H-cyclopenta[d]pyrimidin-4-yl)oxy]ethyl\}-1-oxa-9azaspiro[5.5] undecane ditrifluoroacetate (11g)

Viscous oil, yield 40\%; ${ }^{1} \mathrm{H}$ NMR (300 MHz, DMSO-d 6 ) $\delta 8.42(\mathrm{~s}, 1 \mathrm{H}), 4.48$ (t, $J=6.58 \mathrm{~Hz}, 2 \mathrm{H}$ ), $3.72-3.63(\mathrm{~m}, 1 \mathrm{H}), 3.54-3.44(\mathrm{~m}, 1 \mathrm{H}), 3.11-2.97(\mathrm{~m}, 5 \mathrm{H}), 2.90-2.81(\mathrm{~m}, 1 \mathrm{H}), 2.75(\mathrm{t}, J=$ $7.55 \mathrm{~Hz}, 2 \mathrm{H}), 2.37-2.29$ (m, 1H), $2.27-2.18$ (m, 1H), $2.16-2.05$ (m, 2H), $1.90-1.77$ (m, 1H), 1.71 - 1.52 (m, 6H), 1.47 - 1.36 (m, 1H), 1.25 - 1.01 (m, 6H); ${ }^{13} \mathrm{C}$ NMR (75 MHz, DMSO-d 6 ) $\delta$ 168.7, 168.0, 166.6, 118.5, 68.1, 65.0, 60.0, 41.8, 35.4, 35.1, 31.9, 31.8, 26.5, 26.0, 25.5, 21.5, 15.6, 11.6; MS m/z $358.2\left(\mathrm{M}+\mathrm{H}^{+}\right)$.

4.1.9 4-\{2-[(4-Methylpyridin-2-yl)oxy]ethyl\}-1-oxa-9-azaspiro[5.5]undecane ditrifluoroacetate (11h)

Viscous oil, yield 33\%; ${ }^{1} \mathrm{H}$ NMR (300 MHz, DMSO- $\left.d_{6}\right) \delta 8,03$ (d, $\left.J=5.35 \mathrm{~Hz}, 1 \mathrm{H}\right), 6.86$ (d, $J=$ $6.12 \mathrm{~Hz}, 1 \mathrm{H}), 6.73$ (s, 1H), 4.29 (t, $J=6.59 \mathrm{~Hz}, 2 \mathrm{H}), 3.71-3.62$ (m, 1H), $3.56-3.43$ (m, 1H), $3.13-2.98$ (m, 3H), $2.92-2.79$ (m, 1H), $2.39-2.27$ (m, 4H), $1.92-1.78$ (m, 1H), $1.72-1.52$ (m, 6H), 1.47 - 1.35 (m, 1H), 1.23 - 0.99 (m, 2H); ${ }^{13} \mathrm{C}$ NMR (75 MHz, DMSO-d 6 ) $\delta 163.0,151.6$, 145.2, 118.5, 110.6, 68.1, 63.5, 60.1, 41.8, 35.6, 35.4, 32.1, 26.5, 25.6, 20.5; MS m/z 291.4 $\left(\mathrm{M}+\mathrm{H}^{+}\right)$.

4.1.10 4-\{2-[(6-Methylpyridin-2-yl)oxy]ethyl\}-1-oxa-9-azaspiro[5.5] undecane ditrifluoroacetate (11i)

Viscous oil, yield 40\%; ${ }^{1} \mathrm{H}$ NMR (300 MHz, DMSO- $\left.d_{6}\right) \delta 7.67-7.60$ (m, 1H), 6.85 (d, $J=7.27$ Hz, 1H), 6.65 (d, $J=8.28 \mathrm{~Hz}, 1 \mathrm{H}), 4.28$ (t, $J=6.59 \mathrm{~Hz}, 2 \mathrm{H}), 3.71-3.64$ (m, 1H), $3.54-3.44$ (m, 1H), 3.08 - 2.82 (m, 4H), 2.38 (s, 3H), 2.36 - 2.29 (m, 1H), 1.92 - 1.80 (m, 1H), 1.71 - 1.55 (m, 6H), 1.48 - 1.34 (m, 1H), $1.15-0.99$ (m, 2H); ${ }^{13} \mathrm{C}$ NMR (75 MHz, DMSO-d $) \delta 162.5,155.2$, 
140.2, 116.0, 107.3, 68.1, 63.1, 60.1, 41.9, 35.6, 35.4, 32.1, 26.5, 25.6, 23.3; MS m/z 291.2 $\left(\mathrm{M}+\mathrm{H}^{+}\right)$.

\subsubsection{4-[2-(Pyrimidin-2-yloxy)ethyl]-1-oxa-9-azaspiro[5.5] undecane ditrifluoroacetate (11j)}

Viscous oil, yield 58\%; ${ }^{1} \mathrm{H}$ NMR (300 MHz, DMSO-d $\left.d_{6}\right) \delta 8.59(\mathrm{~s}, 1 \mathrm{H}), 8.57(\mathrm{~s}, 1 \mathrm{H}), 7.11(\mathrm{t}, J=$ $4.75 \mathrm{~Hz}, 1 \mathrm{H}), 4.34$ (t, $J=6.50 \mathrm{~Hz}, 2 \mathrm{H}), 3.72-3.62$ (m, 1H), $3.56-3.43$ (m, 1H), 3.13 - 2.99 (m, 3H), 2.91 - 2.79 (m, 1H), 2.38 - 2.30 (m, 1H), 1.94 - 1.78 (m, 1H), 1.72 - 1.53 (m, 6H), 1.48 $1.36(\mathrm{~m}, 1 \mathrm{H}), 1.22$ - 0.98 (m, 2H); ${ }^{13} \mathrm{C}$ NMR (75 MHz, DMSO-d 6 ) $\delta$ 164.7, 159.6, 115.4, 68.1,

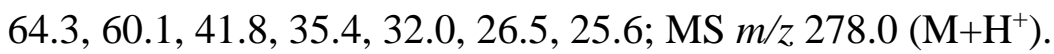

4.1.12 4-\{2-[(3-Methylpyrazin-2-yl)oxy]ethyl\}-1-oxa-9-azaspiro[5.5] undecane ditrifluoroacetate (11k)

Viscous oil, yield 46\%; ${ }^{1} \mathrm{H}$ NMR (300 MHz, DMSO- $d_{6}$ ) $\delta 8.44$ (dd, $J=55.56,2.37 \mathrm{~Hz}, 2 \mathrm{H}$ ), 8.08 - 7.98 (m, 2H), 4.35 (t, $J=6.57 \mathrm{~Hz}, 2 \mathrm{H}), 3.67$ (dd, $J=11.73,4.47 \mathrm{~Hz}, 1 \mathrm{H}), 3.49$ (dd, $J=19.25$, $8.64 \mathrm{~Hz}, 1 \mathrm{H}), 3.14-2.75$ (m, 4H), 2.40 - 2.29 (m, 4H), 1.95 - 1.78 (m, 1H), 1.75 - 1.32 (m, 7H), $1.23-0.99$ (m, 2H); ${ }^{13} \mathrm{C}$ NMR (75 MHz, DMSO-d $\left.{ }_{6}\right) \delta 157.9,143.9,138.3,135.4,68.1,63.4,60.1$, 41.8, 35.4, 35.3, 32.1, 26.7, 25.5, 19.0; MS m/z $292.5\left(\mathrm{M}+\mathrm{H}^{+}\right)$.

\subsubsection{4-[2-(Pyridin-4-yloxy)ethyl]-1-oxa-9-azaspiro[5.5] undecane ditrifluoroacetate (11I)}

Viscous oil, yield 58\%; ${ }^{1} \mathrm{H}$ NMR (300 MHz, DMSO-d 6 ) 8.77 (d, $\left.J=7.32 \mathrm{~Hz}, 2 \mathrm{H}\right), 7.56$ (d, $J=$ $7.36 \mathrm{~Hz}, 2 \mathrm{H}), 4.38$ (t, $J=6.59 \mathrm{~Hz}, 2 \mathrm{H}), 3.73-3.64$ (m, 1H), $3.56-3.45$ (m, 1H), $3.14-2.97$ (m, 3H), 2.93 - 2.78 (m, 1H), 2.37 - 2.29 (m, 1H), 1.95 - 1.81 (m, 1H), $1.74-1.54(\mathrm{~m}, 6 \mathrm{H}), 1.49$ 1.36 (m, 1H), 1.24 - 1.01 (m, 2H); ${ }^{13} \mathrm{C}$ NMR (75 MHz, DMSO-d $\left.{ }_{6}\right) \delta 170.6,143.4,112.98,68.1$, 60.0, 41.5, 35.3, 34.9, 31.8, 26.3, 25.5; MS m/z $276.8\left(\mathrm{M}+\mathrm{H}^{+}\right)$.

\subsubsection{General procedure 2 (GP2): preparation of 1-oxa-9-azaspiro[5.5] undecanes 11a and 11m}

To a $0{ }^{\circ} \mathrm{C}$ solution of $\mathbf{1 3}(1.0 \mathrm{~g}, 3.3 \mathrm{mmol})$, hydroxyaromatic coupling partner (4.3 mmol) and triphenylphosphine (1.29 g, $4.9 \mathrm{mmol})$ in dry THF (100 mL) a solution of DIAD (1.0 g, $4.9 \mathrm{mmol})$ in dry THF (10 mL) was added dropwise. The resulting mixture was stirred for $16 \mathrm{~h}$ at r.t., poured into water $(100 \mathrm{~mL})$ and the resulting slurry extracted with ethyl acetate (3 x $50 \mathrm{~mL})$. The combined organic extracts were dried over anhydrous $\mathrm{Na}_{2} \mathrm{SO}_{4}$, filtered and concentrated in vacuo. The residue was dissolved in 7:3 diethyl ether-hexane mixture $(30 \mathrm{~mL})$ and the solution cooled to $5{ }^{\circ} \mathrm{C}$. The precipitate of triphenylphosphine oxide was filtered off and the filtrate concentrated in vacuo. The residue was fractionated on a short column of silica gel using $0 \rightarrow 5 \%$ ethyl acetate in hexane as eluent. The fractions containing the Mitsunobu reaction product (according to LC MS 
analysis) were pooled and the solvent was evaporated. The residue was dissolved in $\mathrm{CH}_{2} \mathrm{Cl}_{2}(10$ $\mathrm{mL}$ ), the solution was cooled to $0{ }^{\circ} \mathrm{C}$ and TFA ( $3 \mathrm{~mL}$ ) was added. The mixture thus obtained was stirred at $0{ }^{\circ} \mathrm{C}$ for $6 \mathrm{~h}$ and then concentrated in vacuo to dryness to provide, after crystallization from isopropyl alcohol, the target compounds as mono- (11a) or ditrifluoroacetate (11m) salts.

\subsubsection{4-[2-(4-Fluorophenoxy)ethyl]-1-oxa-9-azaspiro[5.5] undecane hydrochloride (11a)}

The trifluoroacetate salt obtained according to GP2, was transformed into hydrochloride salt by trituration with $4 \mathrm{M}$ solution of $\mathrm{HCl}$ in 1,4-dioxane (to avoid absorption of moisture by the hygroscopic TFA salt).

White crystals, $\mathrm{mp}=183-186{ }^{\circ} \mathrm{C}$, yield 64\%; ${ }^{1} \mathrm{H}$ NMR (300 MHz, DMSO- $\left.d_{6}\right) \delta 8.95(\mathrm{~s}, 2 \mathrm{H}), 7.13$ - 7.06 (m, 2H), $6.96-6.90$ (m, 2H), 3.96 (t, $J=6.41 \mathrm{~Hz}, 2 \mathrm{H}), 3.69-3.62(\mathrm{~m}, 1 \mathrm{H}), 3.52-3.44$ (m, 1H), $3.07-2.74(\mathrm{~m}, 4 \mathrm{H}), 2.33-2.29(\mathrm{~m}, 1 \mathrm{H}), 1.87-1.44(\mathrm{~m}, 8 \mathrm{H}), 1.19-0.97(\mathrm{~m}, 2 \mathrm{H}) ;{ }^{13} \mathrm{C}$ NMR (75 MHz, DMSO-d $\left._{6}\right) \delta 156.4$ (d, $\left.J=235.6 \mathrm{~Hz}\right), 154.9$ (d, $\left.J=1.73 \mathrm{~Hz}\right), 115.8$ (d, $J=16.6$ Hz), 115.6 (d, $J=1.2 \mathrm{~Hz}$ ), 68.2, 65.5, 60.0, 41.8, 35.7, 35.2, 32.0, 26.4, 25.4; MS m/z 294.5 $\left(\mathrm{M}+\mathrm{H}^{+}\right)$.

\subsubsection{4-[2-(Pyridin-3-yloxy)ethyl]-1-oxa-9-azaspiro[5.5] undecane ditrifluoroacetate (11m)}

Viscous oil, yield 48\%. ${ }^{1} \mathrm{H}$ NMR (300 MHz, DMSO-d $\left.d_{6}\right) \delta 8.66$ - 8.63 (m, 1H), 8.51- 8.46 (m, 1H), 8.09 - 8.05 (m, 1H), $7.92-7.85$ (m, 1H), 4.23 (t, J = 6.5 Hz, 2H), 3.73 - 3.65 (m, 1H), 3.55 - 3.45 (m, 1H), 3.13 - 2.99 (m, 3H), 2.93 - 2.80 (m, 1H), 2.38 - 2.30 (m, 1H), 1.97 - 1.83 (m, 1H), 1.74 - 1.55 (m, 6H), 1.49 - 1.37 (m, 1H), 1.23 - 1.01 (m, 2H); ${ }^{13} \mathrm{C}$ NMR (75 MHz, DMSO$\left.d_{6}\right) \delta 156.6,135.7,131.1,129.8,127.2,68.1,67.0,60.1,41.7,35.4,35.3,31.9,26.4,25.6 ; \mathrm{MS} \mathrm{m} / \mathrm{z}$ $277.4\left(\mathrm{M}+\mathrm{H}^{+}\right)$.

\subsubsection{General procedure 3 (GP3): preparation of compounds $\mathbf{9 a - m}$}

A solution of the respective spirocyclic piperidine salt 11a-m $(0.46 \mathrm{mmol})$ in $\mathrm{CH}_{2} \mathrm{Cl}_{2}(5 \mathrm{~mL})$ was treated with triethylamine ( $n \times 0.46 \mathrm{mmol}$, where $n=$ number of salt parts per molecule) followed by a solution of $10(0.44 \mathrm{mmol})$ in $\mathrm{CH}_{2} \mathrm{Cl}_{2}(5 \mathrm{~mL})$. After a brief stirring (15 min), sodium triacetoxyborohydride (STAB, $1.32 \mathrm{mmol}$ ) was added and the stirring continued for $12 \mathrm{~h}$ at $\mathrm{r}$. t. The reaction was poured into $10 \%$ aqueous $\mathrm{NaHCO}_{3}(20 \mathrm{~mL})$. Organic phase was separated and the aqueous phase was extracted with $\mathrm{CH}_{2} \mathrm{Cl}_{2}(2 \times 10 \mathrm{~mL})$. The combined organic extracts were washed with brine, dried over anhydrous $\mathrm{Na}_{2} \mathrm{SO}_{4}$, filtered and concentrated in vacuo. The residue was fractionated on silica gel using $0 \rightarrow 1 \% \mathrm{MeOH}$ in $\mathrm{CH}_{2} \mathrm{Cl}_{2}$. The fractions containing the reductive amination product (according to LC MS analysis) were pooled and concentrated in vacuo. The residue was dissolved in $\mathrm{CH}_{2} \mathrm{Cl}_{2}(3 \mathrm{~mL})$ and treated with TFA (1 mL). The mixture 
was stirred at r. t. for $18 \mathrm{~h}$ and concentrated in vacuo. $2 \mathrm{M} \mathrm{HCl}$ in ether ( $3 \mathrm{~mL}$ ) was added to the residue and the later was triturated (with occasional sonication) until a crystalline hydrochloride salt formed. The latter was separated by filtration, washed with ether and dried in vacuo to provide analytically pure compounds $\mathbf{9 a - m}$.

4.1.17 3-(4-\{[4-(\{4-[2-(4-Fluorophenoxy)ethyl]-1-oxa-9-azaspiro[5.5]undec-9yl\}methyl)benzyl]oxy\}phenyl)propanoic acid hydrochloride (9a)

White crystalline solid, $\mathrm{mp}=198-201{ }^{\circ} \mathrm{C}$, yield $83 \mathrm{mg}$ (0.132 mmol, 30\%); ${ }^{1} \mathrm{H}$ NMR (300 MHz, DMSO-d $\left.{ }_{6}\right) \delta 11.11(\mathrm{~s}, 1 \mathrm{H}), 7.67(\mathrm{~d}, J=7.91 \mathrm{~Hz}, 2 \mathrm{H}), 7.49$ (d, $\left.J=7.91 \mathrm{~Hz}, 2 \mathrm{H}\right), 7.13$ (d, $J=8.56$ Hz, 2H), 7.08 (t, $J=8.74$ Hz, 2H), $6.95-6.90$ (m, 4H), 5.09 (s, 2H), $4.39-4.23$ (m, 2H), 3.97 (t, $J=6.50 \mathrm{~Hz}, 2 \mathrm{H}), 3.70-3.60$ (m, 1H), $3.53-3.45$ (m, 1H), $3.13-2.85$ (m, 4H), 2.75 (t, $J=7.55$ Hz, 2H), 2.48 (t, J = 7.55 Hz, 2H), 2,45 - 4.41 (m, 1H), $2.05-1.47$ (m, 8H), 1.17 - 1.02 (m, 2H); ${ }^{13} \mathrm{C}$ NMR (75 MHz, DMSO-d 6 ) $\delta$ 173.7, 156.5, 156.3 (d, $\left.J=235.4 \mathrm{~Hz}\right), 154.9$ (d, $\left.J=1.9 \mathrm{~Hz}\right)$, 138.5, 133.1, 131.5, 129.3, 129.2, 127.7, 115.7 (d, $J=22.4$ Hz), 115.6, 114.5, 68.6, 67.8, 65.5, 60.0, 58.3, 46.9, 46.9, 41.8, 35.7, 35.5, 32.0, 29.4, 26.6, 25.5; HRMS (ESI), m/z calcd for $\mathrm{C}_{34} \mathrm{H}_{40} \mathrm{FNO}_{5}\left[\mathrm{M}+\mathrm{H}^{+}\right]$562.2969, found 562.2963.

4.1.18

3-\{4-[(4-\{[4-(2-\{[5-(Trifluoromethyl)pyridin-2-yl]oxy\}ethyl)-1-oxa-9azaspiro[5.5] undec-9-yl]methyl\}benzyl)oxy] phenyl\}propanoic acid dihydrochloride (9b)

White crystalline solid, mp = 198-201 ${ }^{\circ} \mathrm{C}$, yield $40 \mathrm{mg}$ (0.059 mmol, 13.4\%); ${ }^{1} \mathrm{H}$ NMR (300 MHz, DMSO-d $)_{6} \delta 10.60(\mathrm{~s}, 1 \mathrm{H}), 8.56(\mathrm{~s}, 1 \mathrm{H}), 8.04\left(\mathrm{dd}, J_{1}=2.31 \mathrm{~Hz}, J_{2}=8.87 \mathrm{~Hz}, 1 \mathrm{H}\right), 7.50\left(\mathrm{dd}, J_{1}=\right.$ $\left.7.86 \mathrm{~Hz}, J_{2}=37.80 \mathrm{~Hz}, 4 \mathrm{H}\right), 7.13$ (d, $\left.J=8.54 \mathrm{~Hz}, 2 \mathrm{H}\right), 7.04-6.95$ (m, 1H), 6.92 (d, $J=8.51 \mathrm{~Hz}$, 2H), 5.09 (s, 2H), 4.38 - 4.27 (m, 4H), $3.69-3.61$ (m, 1H), 3.58 - 3.41 (m, 1H), 3.15 - 2.83 (m, 4H), 2.74 (t, $J=7.55 \mathrm{~Hz}, 2 \mathrm{H}), 2.48$ (t, $J=7.55 \mathrm{~Hz}, 2 \mathrm{H}), 2.44-2.40$ (m, 1H), $2.02-1.78$ (m, 2H), $1.69-1.40$ (m, 4H), 1.23 - 0.97 (m, 2H); ${ }^{13} \mathrm{C}$ NMR (75 MHz, DMSO-d $\left.{ }_{6}\right) \delta$ 173.8, 165.6, 156.5, 145.0 (q, $J=4.3 \mathrm{~Hz}), 138.5,136.4$ (q, $J=2.9 \mathrm{~Hz}), 133.1,131.5,129.3,129.27,127.8,124.1$ (q, $J$ = 271.1 Hz), 118.6 (q, $J=32.4 \mathrm{~Hz}$ ), 114.5, 111.4, 68.6, 67.8, 63.9, 60.0, 58.4, 47.0, 46.9, 41.8, 35.5, 35.5, 32.0, 30.7, 29.5, 26.6, 25.6; HRMS (ESI), $\mathrm{m} / \mathrm{z}$ calcd for $\mathrm{C}_{34} \mathrm{H}_{39} \mathrm{~F}_{3} \mathrm{~N}_{2} \mathrm{O}_{5}\left[\mathrm{M}+\mathrm{H}^{+}\right]$ 613.2889, found 613.2883.

4.1.19

3-(4-\{[4-(\{4-[2-(Quinolin-2-yloxy)ethyl]-1-oxa-9-azaspiro[5.5]undec-9yl\}methyl)benzyl]oxy\}phenyl)propanoic acid dihydrochloride (9c)

White crystalline solid, mp = 118- $124{ }^{\circ} \mathrm{C}$, yield $136 \mathrm{mg}$ (0.204 mmol, 44.3\%); ${ }^{1} \mathrm{H}$ NMR (300 MHz, DMSO-d $)_{6} \delta 10.88(\mathrm{~s}, 1 \mathrm{H}), 8.24$ (d, $\left.J=8.9 \mathrm{~Hz}, 1 \mathrm{H}\right), 7.87$ (d, $\left.J=7.8 \mathrm{~Hz}, 1 \mathrm{H}\right), 7.77$ (d, $J=8.1 \mathrm{~Hz}$, 1H), 7.64 (d, $J=8.0 \mathrm{~Hz}, 3 \mathrm{H}), 7.49$ (d, $J=7.9 \mathrm{~Hz}, 2 \mathrm{H}), 7.42$ (t, $J=7.4 \mathrm{~Hz}, 1 \mathrm{H}), 7.13$ (d, $J=8.4$ 
$\mathrm{Hz}, 2 \mathrm{H}), 7.00$ (d, $J=8.8 \mathrm{~Hz}, 1 \mathrm{H}), 6.91(\mathrm{~d}, J=8.4 \mathrm{~Hz}, 2 \mathrm{H}), 5.08(\mathrm{~s}, 2 \mathrm{H}), 4.45(\mathrm{t}, J=6.4 \mathrm{~Hz}, 2 \mathrm{H})$, $4.37-4.25$ (m, 2H), $3.70-3.62$ (m, 1H), 3.49 (t, $J=11.9$ Hz, 1H), $3.14-2.82$ (m, 2H), 2.74 (t, $J$ $=7.5 \mathrm{~Hz}, 2 \mathrm{H}), 2.46(\mathrm{t}, J=7.7 \mathrm{~Hz}, 2 \mathrm{H}), 2.46-2.41(\mathrm{~m}, 1 \mathrm{H}), 2.05-1.85(\mathrm{~m}, 2 \mathrm{H}), 1.73-1.50(\mathrm{~m}$, 6H), 1.25 - 1.01 (m, 2H); ${ }^{13} \mathrm{C}$ NMR (75 MHz, DMSO-d $\left.{ }_{6}\right) \delta 173.8,161.6,156.6,145.5,139.7$, 138.5, 133.1, 131.6, 129.9, 129.3, 129.3, 127.8, 126.4, 124.7, 124.2, 117.0, 114.6, 112.9, 68.7, 67.9, 66.4, 63.3, 60.1, 58.4, 47.0, 46.9, 42.0, 35.6, 32.1, 30.7, 29.5, 26.8, 25.6; HRMS (ESI), m/z calcd for $\mathrm{C}_{37} \mathrm{H}_{42} \mathrm{~N}_{2} \mathrm{O}_{5}\left[\mathrm{M}+\mathrm{H}^{+}\right]$595.3172, found 595.3166.

4.1.20 3-[4-(\{4-[(4-\{2-[(3,6-Dimethylpyrazin-2-yl)oxy]ethyl\}-1-oxa-9-azaspiro[5.5]undec-9yl)methyl]benzyl \}oxy)phenyl]propanoic acid dihydrochloride (9d)

White crystalline solid, $\mathrm{mp}=137-144{ }^{\circ} \mathrm{C}$, yield $81 \mathrm{mg}$ (0.126 mmol, 27.4\%); ${ }^{1} \mathrm{H}$ NMR (300 MHz, DMSO-d $\left._{6}\right) \delta 11.14(\mathrm{~s}, 1 \mathrm{H}), 7.92(\mathrm{~s}, 1 \mathrm{H}), 7.66$ (d, $\left.J=7.41 \mathrm{~Hz}, 2 \mathrm{H}\right), 7.48$ (d, $\left.J=7.59 \mathrm{~Hz}, 2 \mathrm{H}\right), 7.13$ (d, $J=8.19 \mathrm{~Hz}, 2 \mathrm{H}), 6.91$ (d, $J=8.14 \mathrm{~Hz}, 2 \mathrm{H}), 5.08$ (s, 2H), $4.36-4.23$ (m, 4H), $3.69-3.62$ (m, 1H), 3.55 - 3.43 (m, 1H), $3.12-2.81(\mathrm{~m}, 4 \mathrm{H}), 2.74(\mathrm{t}, \mathrm{J}=6.95 \mathrm{~Hz}, 2 \mathrm{H}), 2.48(\mathrm{t}, J=6.95 \mathrm{~Hz}, 2 \mathrm{H})$, $2.38-2.32$ (m, 7H), $2.05-1.98$ (m, 1H), $1.92-1.79(\mathrm{~m}, 1 \mathrm{H}), 1.72-1.49(\mathrm{~m}, 6 \mathrm{H}), 1.21-1.03$ (m, 2H); ${ }^{13} \mathrm{C}$ NMR (75 MHz, DMSO-d $) \delta 173.9,157.3,156.6,148.1,139.8,138.5,133.2,133.0$, 131.7, 129.4, 129.3, 127.9, 114.6, 68.7, 67.9, 63.4, 60.1, 58.4, 47.0, 47.0, 35.6, 35.5, 35.3, 32.2, 30.8, 29.5, 26.8, 25.5, 20.5, 18.1; HRMS (ESI), $m / z$ calcd for $\mathrm{C}_{34} \mathrm{H}_{43} \mathrm{~N}_{3} \mathrm{O}_{5}\left[\mathrm{M}+\mathrm{H}^{+}\right]$574.3281, found 574.3275 .

4.1.21 3-(4-\{[4-(\{4-[2-(6,7-Dihydro-5H-cyclopenta[d]pyrimidin-4-yloxy)ethyl]-1-oxa-9azaspiro[5.5] undec-9-yl\}methyl)benzyl]oxy\}phenyl)propanoic acid dihydrochloride (9e)

Amorphous solid, yield $44 \mathrm{mg}$ (0.067 mmol, 14.6\%); ${ }^{1} \mathrm{H}$ NMR (300 MHz, DMSO-d 6 ) $\delta 10.87$ (s, 1H), 8.73 (s, 1H), 7.64 (d, $J=7.9 \mathrm{~Hz}, 2 \mathrm{H}), 7.49$ (d, $J=7.9 \mathrm{~Hz}, 2 \mathrm{H}), 7.13$ (d, $J=8.5 \mathrm{~Hz}, 2 \mathrm{H}), 6.91$ (d, $J=8.5 \mathrm{~Hz}, 2 \mathrm{H}$ ), 5.08 (s, 2H), 4.47 (t, $J=6.6 \mathrm{~Hz}, 2 \mathrm{H}), 4.40-4.24$ (m, 2H), 3.65 (dd, $J=11.3$, $3.8 \mathrm{~Hz}, 1 \mathrm{H}), 3.57-3.42$ (m, 1H), $3.15-2.70$ (m, 10H), 2.46 (t, $J=7.2 \mathrm{~Hz}, 2 \mathrm{H}), 2.45-2.38$ (m, 1H), 2.13 - 2.02 (m, 2H), 2.01 - 1.52 (m, 8H), 1.27 - 1.01 (m, 2H); ${ }^{13} \mathrm{C}$ NMR (75 MHz, DMSO$\left.d_{6}\right) \delta 173.8,171.7,165.9,156.5,154.9,138.5,133.1,131.6,129.3,129.2,127.8,120.7,114.5$, 68.6, 67.8, 64.4, 60.0, 58.3, 47.0, 46.9, 41.8, 35.5, 35.2, 32.7, 32.0, 30.7, 29.5, 26.7, 26.2, 25.5, 21.3; HRMS (ESI), $m / z$ calcd for $\mathrm{C}_{35} \mathrm{H}_{43} \mathrm{~N}_{3} \mathrm{O}_{5}\left[\mathrm{M}+\mathrm{H}^{+}\right]$586.3281, found 586.3294.

4.1.22

3-(4-\{[4-(\{4-[2-(Pyrazin-2-yloxy)ethyl]-1-oxa-9-azaspiro[5.5]undec-9yl\}methyl)benzyl]oxy\}phenyl)propanoic acid dihydrochloride (9f)

White crystalline solid, mp = 196-199 ${ }^{\circ} \mathrm{C}$, yield $92 \mathrm{mg}$ (0.149 mmol, 32.4\%); ${ }^{1} \mathrm{H}$ NMR (300 MHz, $\left.\mathrm{DMSO}_{-} \mathrm{d}_{6}\right) 11.00(\mathrm{~s}, 1 \mathrm{H}), 8.78(\mathrm{t}, J=6.0 \mathrm{~Hz}, 1 \mathrm{H}), 7.81$ (d, $\left.J=6.3 \mathrm{~Hz}, 2 \mathrm{H}\right), 7.66$ (d, $J=8.2 \mathrm{~Hz}$, 
2H), 7.50 (d, $J=8.2 \mathrm{~Hz}, 2 \mathrm{H}), 7.14$ (d, $J=8.7 \mathrm{~Hz}, 2 \mathrm{H}), 6.92$ (d, $J=8.7 \mathrm{~Hz}, 2 \mathrm{H}), 5.09$ (s, 2H), 4.51 (dd, $J=5.6,2.4 \mathrm{~Hz}, 2 \mathrm{H}), 4.42-4.25$ (m, 2H), 3.66 (d, $J=7.6 \mathrm{~Hz}, 1 \mathrm{H}), 3.50$ (t, $J=11.3 \mathrm{~Hz}, 1 \mathrm{H})$, $3.13-2.81$ (m, 4H), 2.75 (t, $J=7.5 \mathrm{~Hz}, 2 \mathrm{H}), 2.47$ (t, $J=7.4 \mathrm{~Hz}, 2 \mathrm{H}), 2.47-2.42(\mathrm{~m}, 1 \mathrm{H}), 2.19$ 1.92 (m, 4H), 1.74 - 1.38 (m, 4H), 1.21 - 1.01 (m, 2H); ${ }^{13} \mathrm{C}$ NMR (75 MHz, DMSO-d $\left.)\right) \delta 174.2$, 172.0, 160.0, 157.0, 142.5, 138.9, 133.6, 132.0, 129.8, 129.7, 128.2, 125.0, 115.0, 69.1, 68.3, 60.4, 58.7, 47.4, 47.4, 42.8, 42.1, 36.0, 35.8, 32.3, 29.9, 27.8, 25.9; HRMS (ESI), $\mathrm{m} / \mathrm{z}$ calcd for $\mathrm{C}_{32} \mathrm{H}_{39} \mathrm{~N}_{3} \mathrm{O}_{5}\left[\mathrm{M}+\mathrm{H}^{+}\right]$546.2968, found 546.2986.

4.1.23 3-[4-(\{4-[(4-\{2-[(2-Cyclopropyl-6,7-dihydro-5H-cyclopenta[d]pyrimidin-4-yl)oxy]ethyl\}1-oxa-9-azaspiro[5.5] undec-9-yl)methyl] benzyl\}oxy)phenyl]propanoic acid dihydrochloride (9g) Amorphous solid, yield 108 mg (0.155 mmol, 33.7\%); ${ }^{1} \mathrm{H}$ NMR (300 MHz, DMSO-d $\left.{ }_{6}\right) \delta 11.10$ (s, 1H), $7.58\left(\mathrm{dd}, J_{1}=8.06 \mathrm{~Hz}, J_{2}=52.18 \mathrm{~Hz}, 4 \mathrm{H}\right.$ ), 7.03 (dd, $\left.J_{1}=8.56 \mathrm{~Hz}, J_{2}=66.37 \mathrm{~Hz}, 4 \mathrm{H}\right), 5.08$ (s, 2H), 4.48 (t, $J=6.58 \mathrm{~Hz}, 2 \mathrm{H}), 4.40-4.24$ (m, 2H), $3.70-3.62(\mathrm{~m}, 1 \mathrm{H}), 3.53-3.43$ (m, 1H), $3.15-2.99(\mathrm{~m}, 5 \mathrm{H}), 2.92-2.83(\mathrm{~m}, 1 \mathrm{H}), 2.79-2.70(\mathrm{~m}, 4 \mathrm{H}), 2.48(\mathrm{t}, J=7.55 \mathrm{~Hz}, 2 \mathrm{H}), 2.44-$ 2.34 (m, 2H), 2.19 - 2.09 (m, 2H), $2.06-1.95$ (m, 1H), 1.89 - 1.76 (m, 1H), 1.72 - 1.43 (m, 6H), 1.31 - $1.02(\mathrm{~m}, 6 \mathrm{H}) ;{ }^{13} \mathrm{C}$ NMR (75 MHz, DMSO-d $) \delta 173.7,167.6,167.5,167.4,166.8,156.5$, 138.5, 133.1, 131.5, 129.3, 129.2, 127.7, 119.1, 114.5, 68.6, 67.8, 65.4, 60.0, 58.3, 46.9, 46.8, 41.8, 35.5, 35.4, 34.9, 31.9, 31.4, 29.5, 26.6, 25.9, 25.4, 21.6, 15.0, 12.0; HRMS (ESI), $\mathrm{m} / \mathrm{z}$ calcd for $\mathrm{C}_{38} \mathrm{H}_{47} \mathrm{~N}_{3} \mathrm{O}_{5}\left[\mathrm{M}+\mathrm{H}^{+}\right]$626.3594, found 626.3574.

4.1.24 3-[4-(\{4-[(4-\{2-[(4-Methylpyridin-2-yl)oxy]ethyl\}-1-oxa-9-azaspiro[5.5]undec-9yl)methyl]benzyl \}oxy)phenyl]propanoic acid dihydrochloride (9h)

White crystalline solid, $\mathrm{mp}=30-32{ }^{\circ} \mathrm{C}$, yield $112 \mathrm{mg}$ (0.177 mmol, 38.5\%); ${ }^{1} \mathrm{H}$ NMR (300 MHz, DMSO- $\left.d_{6}\right) \delta 11.15(\mathrm{~s}, 1 \mathrm{H}), 8.07$ (d, $\left.J=5.49 \mathrm{~Hz}, 1 \mathrm{H}\right), 7.58\left(\mathrm{dd}, J_{1}=8.10 \mathrm{~Hz}, J_{2}=54.84 \mathrm{~Hz}, 4 \mathrm{H}\right.$ ), 7.14 (d, $J=8.69 \mathrm{~Hz}, 2 \mathrm{H}), 6.99-6.87$ (m, 4H), 5.09 (s, 2H), $4.41-4.23$ (m, 4H), 3.69 - 3.62 (m, 1H), $3.56-3.43$ (m, 1H), $3.14-2.99$ (m, 3H), $2.95-2.83$ (m, 1H), 2.75 (t, J = $7.55 \mathrm{~Hz}, 2 \mathrm{H}), 2.48$ (t, $J=7.55 \mathrm{~Hz}, 2 \mathrm{H}), 2.45-2.39$ (m, 1H), 2.34 (s, 3H), $2.09-1.95$ (m, 1H), $1.90-1.78$ (m, 1H), 1.72 - 1.47 (m, 6H), 1.25 - 1.00 (m, 2H); ${ }^{13} \mathrm{C}$ NMR (75 MHz, DMSO-d 6 ) $\delta 173.7,162.1,156.5$, 153.8, 143.6, 138.4, 133.1, 131.6, 129.3, 129.2, 127.7, 118.7, 114.5, 110.7, 68.6, 67.8, 64.6, 60.0, 58.3, 46.9, 46.8, 41.8, 35.5, 35.4, 32.0, 29.5, 26.6, 25.5, 20.8; HRMS (ESI), m/z calcd for $\mathrm{C}_{34} \mathrm{H}_{42} \mathrm{~N}_{2} \mathrm{O}_{5}\left[\mathrm{M}+\mathrm{H}^{+}\right]$559.3172, found 559.3166.

4.1.25 3-[4-(\{4-[(4-\{2-[(6-Methylpyridin-2-yl)oxy]ethyl\}-1-oxa-9-azaspiro[5.5]undec-9yl)methyl]benzyl \}oxy)phenyl]propanoic acid dihydrochloride (9i) 
White crystalline solid, mp = 147-150 ${ }^{\circ} \mathrm{C}$, yield $127 \mathrm{mg}$ (0.202 mmol, 43.9\%); ${ }^{1} \mathrm{H}$ NMR (300 MHz, DMSO-d $\left.{ }_{6}\right) \delta 11.04(\mathrm{~s}, 1 \mathrm{H}), 7.76-7.64(\mathrm{~m}, 3 \mathrm{H}), 7.52-7.47(\mathrm{~m}, 2 \mathrm{H}), 7.14(\mathrm{~d}, J=8.65 \mathrm{~Hz}, 2 \mathrm{H})$, $6.95-6.88$ (m, 3H), $6.78-6.72$ (m, 1H), 5.09 (s, 2H), $4.41-4.24$ (m, 4H), $3.70-3.63$ (m, 1H), $3.55-3.43$ (m, 1H), $3.13-2.83$ (m, 4H), 2.75 (t, $J=7.59$ Hz, 2H), 2.48 (t, $J=7.59 \mathrm{~Hz}, 2 \mathrm{H}), 2.46$ - 2.42 (m, 1H), 2.41 (s, 3H), 2.07 - 1.95 (m, 1H), 1.91 - 1.79 (m, 1H), $1.74-1.45$ (m, 6H), 1.25 - 1.03 (m, 2H); ${ }^{13} \mathrm{C}$ NMR (75 MHz, DMSO-d $\left.{ }_{6}\right) \delta 173.8,162.0,156.5,154.6,138.5,133.1,131.6$, 129.3, 129.2, 127.8, 116.4, 114.5, 107.4, 68.6, 67.8, 64.0, 60.0, 58.3, 47.0, 46.9, 41.9, 35.5, 35.5, 32.0, 29.5, 26.5, 26.6, 25.5, 22.6; HRMS (ESI), $m / z$ calcd for $\mathrm{C}_{34} \mathrm{H}_{42} \mathrm{~N}_{2} \mathrm{O}_{5}\left[\mathrm{M}+\mathrm{H}^{+}\right]$559.3172, found 559.3164 .

4.1.26 3-(4-\{[4-(\{4-[2-(Pyrimidin-2-yloxy)ethyl]-1-oxa-9-azaspiro[5.5]undec-9yl\}methyl)benzyl]oxy\}phenyl)propanoic acid dihydrochloride (9j)

Amorphous solid, yield 112 mg (0.182 mmol, 39.6\%); ${ }^{1} \mathrm{H}$ NMR (300 MHz, DMSO-d $\left.{ }_{6}\right) \delta 11.07$ (s, 1H), $8.31-8.26$ (m, 1H), $8.22-8.17$ (m, 2H), 7.66 (d, $J=7.31 \mathrm{~Hz}, 2 \mathrm{H}), 7.48$ (d, $J=7.51 \mathrm{~Hz}$, 2H), 7.14 (d, $J=8.33 \mathrm{~Hz}, 2 \mathrm{H}), 6.92$ (d, $J=8.42 \mathrm{~Hz}, 2 \mathrm{H}), 5.09$ (s, 2H), $4.39-4.23$ (m, 4H), 3.70 - 3.61 (m, 1H), $3.57-3.42$ (m, 1H), $3.16-3.00$ (m, 3H), $2.95-2.82$ (m, 1H), 2.75 (t, J = 7.55 Hz, 2H), 2.48 (t, $J=7.55$ Hz, 2H), $2.45-2.40$ (m, 1H), $2.08-1.95$ (m, 1H), $1.91-1.77$ (m, 1H), 1.73 - 1.47 (m, 6H), 1.26 - 1.01 (m, 2H); ${ }^{13} \mathrm{C}$ NMR (75 MHz, DMSO-d $\left.{ }_{6}\right) \delta 173.7,159.7,156.5$, 140.8, 138.4, 136.6, 135.2, 133.1, 131.5, 129.2, 127.7, 114.5, 68.6, 67.8, 63.9, 60.0, 58.3, 46.9, 46.8, 41.8, 35.5, 35.4, 35.3, 31.9, 29.4, 26.6, 25.5; HRMS (ESI), $m / z$ calcd for $\mathrm{C}_{32} \mathrm{H}_{39} \mathrm{~N}_{3} \mathrm{O}_{5}\left[\mathrm{M}+\mathrm{H}^{+}\right]$ 546.2968, found 546.2962.

4.1.27 3-[4-(\{4-[(4-\{2-[(3-Methylpyrazin-2-yl)oxy]ethyl\}-1-oxa-9-azaspiro[5.5]undec-9yl)methyl] benzyl \}oxy)phenyl]propanoic acid dihydrochloride (9k)

Amorphous solid, yield $80 \mathrm{mg}$ (0.127 mmol, 27.6\%); ${ }^{1} \mathrm{H}$ NMR (300 MHz, DMSO-d 6 ) $\delta 10.92$ (s, 1H), $8.08-8.00$ (m, 2H), 7.65 (d, $J=8.0 \mathrm{~Hz}, 2 \mathrm{H}), 7.49$ (d, $J=8.0 \mathrm{~Hz}, 2 \mathrm{H}), 7.13$ (d, $J=8.5 \mathrm{~Hz}$, 2H), 6.91 (d, $J=8.5 \mathrm{~Hz}, 2 \mathrm{H}), 5.08$ (s, 2H), $4.39-4.25$ (m, 4H), 3.66 (dd, $J=11.7,4.8 \mathrm{~Hz}, 1 \mathrm{H}$ ), 3.49 (dd, $J=13.0,10.7 \mathrm{~Hz}, 1 \mathrm{H}), 3.15-2.80$ (m, 4H), 2.74 (t, $J=7.5 \mathrm{~Hz}, 2 \mathrm{H}), 2.46$ (t, $J=7.5 \mathrm{~Hz}$, 2H), $2.44-2.36$ (m, 4H), $2.06-1.77$ (m, 2H), $1.72-1.48$ (m, 6H), $1.21-1.00(\mathrm{~m}, 2 \mathrm{H}) ;{ }^{13} \mathrm{C} \mathrm{NMR}$ (75 MHz, DMSO-d $) \delta 173.7,157.9,156.5,143.7,138.5,138.37,135.23,133.14,131.54,129.29$, 129.19, 127.73, 114.59, 68.69, 67.80, 63.41, 60.09, 58.4, 47.0, 46.9, 41.8, 35.5, 35.2, 32.1, 30.6, 29.4, 26.8, 25.5, 18.8; HRMS (ESI), $m / z$ calcd for $\mathrm{C}_{33} \mathrm{H}_{41} \mathrm{~N}_{3} \mathrm{O}_{5}\left[\mathrm{M}+\mathrm{H}^{+}\right]$560.3124, found 560.3116 . 
White crystalline solid, $\mathrm{mp}=33-36{ }^{\circ} \mathrm{C}$, yield $144 \mathrm{mg}$ (0.234 mmol, 50.9\%); ${ }^{1} \mathrm{H}$ NMR (300 MHz, DMSO-d $\left._{6}\right) \delta 11.20(\mathrm{~s}, 1 \mathrm{H}), 8.74(\mathrm{~d}, J=6.86 \mathrm{~Hz}, 2 \mathrm{H}), 7.67$ (d, $\left.J=7.96 \mathrm{~Hz}, 2 \mathrm{H}\right), 7.55$ (d, $J=6.77$ Hz, 2H), 7.48 (d, $J=8.05$ Hz, 2H), 7.13 (d, $J=8.60 \mathrm{~Hz}, 2 \mathrm{H}), 6.92$ (d, $J=8.64 \mathrm{~Hz}, 2 \mathrm{H}$ ), 5.09 (s, 2H), $4.43-4.25$ (m, 4H), 3.70 - 3.63 (m, 1H), $3.54-3.45$ (m, 1H), 3.13 - 2.84 (m, 4H), 2.75 (t, $J=7.55 \mathrm{~Hz}, 2 \mathrm{H}), 2.48$ (t, $J=7.55 \mathrm{~Hz}, 2 \mathrm{H}), 2.45-2.40$ (m, 1H), $2.08-1.96$ (m, 1H), $1.93-1.80$ (m, 1H), $1.76-1.50$ (m, 6H), $1.27-1.05$ (m, 2H); ${ }^{13} \mathrm{C}$ NMR (75 MHz, DMSO-d 6 ) $\delta 175.4,162.3$, 158.3, 152.2, 140.9, 139.9, 132.7, 130.0, 128.9, 127.9, 115.7, 106.1, 76.5, 70.3, 66.4, 62.7, 60.3, 51.3, 38.1, 36.3, 35.9, 35.4, 33.9, 33.7, 32.6, 30.1; HRMS (ESI), $m / z$ calcd for $\mathrm{C}_{33} \mathrm{H}_{40} \mathrm{~N}_{2} \mathrm{O}_{5}\left[\mathrm{M}+\mathrm{H}^{+}\right]$ 545.3015, found 545.3010.

4.1.29

3-(4-\{[4-(\{4-[2-(Pyridin-3-yloxy)ethyl]-1-oxa-9-azaspiro[5.5]undec-9yl\}methyl)benzyl]oxy\}phenyl)propanoic acid dihydrochloride (9m)

White crystalline solid, $\mathrm{mp}=168-171{ }^{\circ} \mathrm{C}$, yield $127 \mathrm{mg}$ (0.206 mmol, 44.8\%); ${ }^{1} \mathrm{H}$ NMR (300 MHz, $\left.\mathrm{DMSO}_{-} \mathrm{d}_{6}\right) \delta 11.11(\mathrm{~s}, 1 \mathrm{H}), 8.73-8.64(\mathrm{~m}, 1 \mathrm{H}), 8.49-8.46(\mathrm{~m}, 1 \mathrm{H}), 8.13-8.08(\mathrm{~m}, 1 \mathrm{H}), 7.94-$ 7.86 (m, 1H), 7.58 (dd, $J=7.96,52.28 \mathrm{~Hz}, 4 \mathrm{H}$ ), 7.02 (dd, $J=8.01,66.37 \mathrm{~Hz}, 4 \mathrm{H}$ ), 5.08 (s, 2H), $4.41-4.21$ (m, 4H), $3.70-3.63(\mathrm{~m}, 1 \mathrm{H}), 3.54-3.45(\mathrm{~m}, 1 \mathrm{H}), 3.15-3.03(\mathrm{~m}, 3 \mathrm{H}), 2.93-2.84$ (m, 1H), 2.75 (t, $J=7.55$ Hz, 2H), 2.48 (t, $J=7.55$ Hz, 2H), $2.44-2.40$ (m, 1H), 2.09 - 1.95 (m, 1H), $1.91-1.80$ (m, 1H), $1.74-1.50$ (m, 6H), 1.24 - 1.04 (m, 2H); ${ }^{13} \mathrm{C}$ NMR (75 MHz, DMSO$\left.d_{6}\right) \delta 173.7,156.6,156.5,138.5,135.1,133.1,131.6,131.1,130.3,130.3,129.3,129.2,127.9$, 127.7, 127.3, 114.6, 68.6, 67.8, 67.1, 60.0, 58.3, 46.9, 46.8, 41.6, 35.5, 35.4, 35.2, 31.9, 29.5, 26.5, 25.5; HRMS (ESI), $m / z$ calcd for $\mathrm{C}_{33} \mathrm{H}_{40} \mathrm{~N}_{2} \mathrm{O}_{5}\left[\mathrm{M}+\mathrm{H}^{+}\right]$545.3015, found 545.3006.

\subsection{Biological and ADME assays}

4.2.1 Determination of agonistic activity of compounds against FFA1 (GPR40), FFA3 (GPR41), FFA2 (GPR43) and FFA4 (GPR120) receptors

CHO cells stably expressing human GPR40 (stable CHO-GPR40 line created at Enamine Ltd.) were seeded (12,500 cells/well) into 384-well black-wall, clear-bottom microtiter plates $24 \mathrm{~h}$ prior to assay. Cells were loaded for $1 \mathrm{~h}$ with fluorescent calcium dye (Fluo-8 Calcium Assay kit, Abcam, ab112129) and tested using fluorometric imaging plate reader (FLIPR Tetra ${ }^{\circledR}$ High Throughput Cellular Screening System, Molecular Devices Corp.). Maximum change in fluorescence over base line was used to determine agonist response. A potent and selective agonist for FFA1 (GPR40) GW9508 (Selleckchem, S8014) was tested with the test compounds as a positive control. Concentration response curve data were fitted using Molecular Devices ScreenWorks ${ }^{\circledR}$ System Control Software (Molecular Devices). For specificity screening for possible GPR41, GPR43 and 
GPR120 agonism, CHO cell lines stably expressing the respective receptors (purchased from The European Collection of Cell Cultures, ECACC) were used.

\subsubsection{Determination of aqueous solubility (PBS, pH 7.4)}

The test compound (9i) and the reference compound (Ondansetron hydrochloride, Sigma-Aldrich, O3639), were assessed for kinetic solubility in phosphate-buffered saline: $138 \mathrm{mM} \mathrm{NaCl}, 2.7 \mathrm{mM}$ KCl, 10 mM K-phosphate, pH 7.4 with 2\% final DMSO. Solubility measurements were done using filter microplate technique with UV-quantification for all compounds. Using a $40 \mathrm{mM}$ stock solution of each compound in $100 \%$ DMSO, dilutions were prepared to a theoretical concentration of $800 \mu \mathrm{M}$ in duplicates in phosphate-buffered saline $\mathrm{pH} 7.4$ with $2 \%$ final dimethyl sulfoxide (DMSO) and then transferred to a 96-well, deep well polypropylene collection plate. In parallel, compound dilutions in 50\% methanol/PBS mixes were prepared at concentrations of $0 \mu \mathrm{M}$ (blank), $200 \mu \mathrm{M}$ and $400 \mu \mathrm{M}$ in duplicates to generate calibration curves. The experimental compound dilutions in PBS were further allowed to equilibrate at $25^{\circ} \mathrm{C}$ on a thermostatic orbital shaker for two hours and then filtered through HTS solubility filter plates (EMD Millipore, MSSLBPC) using a vacuum manifold. The filtrates adjusted for the calibration sample non-aqueous solvent content by 2-fold dilution with methanol, and the calibrating solutions were analyzed using SpectraMax UV-Vis microplate reader (200-550 nm absorbance scan, $5 \mathrm{~nm}$ step increment). The concentrations of compounds in PBS filtrate were determined using a dedicated Microsoft Excel calculation script. Proper absorbance wavelengths for calculations were selected for each compound manually based on absorbance maxima (absolute absorbance unit values for the minimum and maximum concentration points within 0 - 3 OD range). Each of the final datasets was additionally visually evaluated by the operator and goodness of fit (R2) was calculated for each calibration curve. The reference compound was included in every separate solubility experiment to control proper assay performance.

\subsubsection{Assessment of metabolic stability in mouse liver microsomes}

The metabolic stability of compound $\mathbf{9 i}$ as well as the reference compounds (Imipramine, Propranolol) was determined in liver microsomes at five time points over 40 minutes using HPLCMS. Mouse hepatic microsomes were isolated from pooled (50), perfused livers of BALB/c male mice according to the standard protocol [26]. The batch of microsomes was tested for quality control using a commercial comparator preparation (Sigma-Aldrich M9441) and verapamil and propranolol as reference compounds. Microsomal incubations were carried out in 96-well plates in 5 aliquots of $40 \mu \mathrm{L}$ each (one for each time point). Liver microsomal incubation medium contained potassium phosphate buffer (100 mM, pH 7.4), $\mathrm{MgCl}_{2}(3.3 \mathrm{mM}), \mathrm{NADPH}(3 \mathrm{mM})$, 
glucose-6-phosphate (5.3 mM), glucose-6-phosphate dehydrogenase (0.67 units/ml) with $0.42 \mathrm{mg}$ of liver microsomal protein per $\mathrm{mL}$. In addition, control incubations were performed replacing the NADPH-regenerating system with $100 \mathrm{mM}$ phosphate buffer $\mathrm{pH}$ 7.4. Test compounds $(2 \mu \mathrm{M}$, final solvent concentration $1.6 \%$ ) were incubated at $37^{\circ} \mathrm{C}$ under vortexing at $100 \mathrm{rpm}$. Five time points over 40 minutes had been analyzed. The reactions were stopped by adding 12 volumes of $90 \%$ acetonitrile-water to $40 \mu \mathrm{L}$ incubation aliquots, followed by plasma protein precipitation by centrifuging at $5500 \mathrm{rpm}$ for 3 minutes. Incubations were performed in duplicates. Supernatants were analyzed using the HPLC system coupled with tandem mass spectrometer. The elimination constant $\left(\mathrm{kel}_{\mathrm{el}}\right)$, half-life $\left(\mathrm{T}_{1 / 2}\right)$ and intrinsic clearance $\left(\mathrm{Cl}_{\text {int }}\right)$ were determined in plot of $\ln (\mathrm{AUC})$ versus time, using linear regression analysis:

$\mathrm{k}_{\mathrm{el}}=-$ slope

$\mathrm{T}_{1 / 2}=0.693 / \mathrm{kel}_{\mathrm{el}}$

$\mathrm{CL}_{\text {int }}=\left(0.693 / \mathrm{T}_{1 / 2}\right) \times(\mu \mathrm{l}$ incubation $/ \mathrm{mg}$ microsomes $)$

\subsubsection{Caco-2 permeability assay.}

Caco-2 cells (human colorectal adenocarcinoma line, ATCC, Cat. HTB-37) were cultivated in DMEM medium supplemented with 10\% FBS, 1\% non-essential amino acids solution and 0,1\% penicillin-streptomycin in humidified atmosphere at 37oC in 5\% CO2 to $70-80 \%$ confluence and then were seeded at 1x105 cells/well on 24-well semipermeable insert plates (Millicell Multiwell PCF $0.4 \mu \mathrm{m}$ or similar). The medium was changed every two days. After 10 days of cell growth the integrity of differentiated Caco-2 monolayers was verified by transepithelial electrical resistance (TEER) measurements using Milicell-ERS Voltohmmeter (Millipore EMD). Caco-2 cell monolayers were considered acceptable for transport studies if the final values of TEER were greater than $1000 \mathrm{ohm} / \mathrm{cm}^{2}$. For the permeability studies, 24-well insert plate was removed from its feeder plate and placed in a new sterile 24-well receiver plate. The cell layer was washed twice with Phosphate-Buffered Saline. Aliquots (300 $\mu \mathrm{L}$ ) of the test compound solution (in duplicates, at $10 \mu \mathrm{M}$, in HBSS with 5,6 mM glucose buffered with $10 \mathrm{mM}$ HEPES, $\mathrm{pH}$ 7.4) were added into the apical compartments of the trans-well insert and $1000 \mu \mathrm{L}$ of the same buffer was added to the basolateral compartments. The plates were then incubated for $2 \mathrm{~h}$ at $37{ }^{\circ} \mathrm{C}$. High, low and intermediate permeability controls (Atenolol, Propranolol, Quinidine) were run with every experimental batch to verify assay validity. The concentrations of the compounds tested in the AB permeability assay were determined using HPLC-MS method. The LC system comprised Shimadzu liquid chromatograph equipped with isocratic pumps (Shimadzu LC-10ADvp), autosampler (Shimadzu SIL-HTc), switching valve (FCV-14AH) and degasser (Shimadzu DGU14A). Mass spectrometric analysis was performed using API 3000 (triple-quadrupole) instrument 
from PE Sciex with electro-spray (ESI) interface. The data acquisition and system control were performed using Analyst 1.5.2 software from PE Sciex.

The formula for calculating Papp (expressed in $10^{-6} \mathrm{~cm} / \mathrm{sec}$ ) was as follows:

$$
\text { Papp }=(\text { VA/((Area) } \times(\text { Time })) \times\left([\text { drug }]_{\text {acd }} /[\text { drug }]_{\text {init,d }}\right), \text { where }
$$

VA - volume of transport buffer in acceptor well,

Area - surface area of the insert (equals to effective growth area of the insert),

Time - time of the assay,

[drug] $]_{\text {acc }}$ - concentration of test compound in the acceptor well,

[drug] $]_{\text {init,d }}$ - initial concentration of test compound in the donor well.

\subsection{Docking studies}

The 3D coordinates for GPR40 co-crystalized with TAK-875 was obtained from the Protein Data Bank (PDB ID: 4PHU) [27] and used for subsequent docking procedures. Protein preparation, refinement and docking was performed within Schrodinger's Maestro, version 2016-1 [28]. To prepare FFA1 receptor for docking, hydrogens and missing atoms were added, alternate residue positions were defined and the hydrogen bonding network was further optimized by re-orientating hydroxyls, amides and imidazole rings (of histidine residues) using the Protein Preparation Wizard [29]. For selecting an appropriate docking protocol, TAK-875 was re-docked onto FFA1 and compared to the crystal structure orientation, RMSD $<2.5 \AA$. - The remaining parameters and steps for receptor grid generation, ligand preparation and docking protocols were similar to the methodology of our previous studies [14b, 17]. Here we utilized the MacroModel [30], LigPrep [31] and GLIDE [32] modules of Schrödinger's Maestro. To allow the comparison of residue positions within the GPCR family, the labels of residues are shown the Ballesteros Weinstein indexing system in subscript [24].

\section{Acknowledgements}

This research was supported by the Russian Scientific Fund (project grant 14-50-00069). We are grateful to the Center for Chemical Analysis and Materials Research of Saint-Petersburg State University for providing high-resolution mass-spectrometry data.

\section{Appendix A. Supplementary data}

Supplementary data related to this article can be found at http://dx.doi.org/xxx.

\section{References}


[1] C.P. Briscoe, M. Tadayyon, J.L. Andrews, W.G. Benson, J.K. Chambers, M.M. Eilert, C. Ellis, N.A. Elshourbagy, A.S. Goetz, D.T. Minnick, P.R. Murdock, H.R. Sauls, U. Shabon, L.D. Spinage, J.C. Strum, P.G. Szekeres, K.B. Tan, J.M. Way, D.M. Ignar, S. Wilson, A.I. Muir, The orphan G protein-coupled receptor GPR40 is activated by medium and long chain fatty acids. J. Biol. Chem. 278 (2003) 11303-11311.

[2] M. Kebede, M. Ferdaoussi, A. Mancini, T. Alquier, R.N. Kulkarni, M.D. Walker, V. Poitout, Glucose activates free fatty acid receptor 1 gene transcription via phosphatidylinositol-3-kinasedependent $O$-GlcNAcylation of pancreas-duodenum homeobox-1. Proc. Natl. Acad. Sci. U.S.A. 109 (2012) 2376-2381.

[3] K.R. Waterson, B.D. Hudson, T. Ulven, G. Milligan, Treatment of type 2 diabetes by free fatty acid receptor agonists. Front. Endocrinol. 5 (2014) 137.

[4] E. Defossa, M. Wagner, Recent developments in the discovery of FFA1 receptor agonists as novel oral treatment for type 2 diabetes mellitus. Bioorg. Med. Chem. Lett. 24 (2014) 2991-3000.

[5] Z. Li, Q. Qiu, X. Geng, J. Yang, W. Huang, H. Qian, Free fatty acid receptor agonists for the treatment of type 2 diabetes: drugs in preclinical to phase II clinical development. Expert Opin. Investig. Drugs 2016, DOI: 10.1080/13543784.2016.1189530.

[6] K. Kaku, K. Enya, R. Nakaya, T. Ohira, R. Matsuno, Efficacy and safety of fasiglifam (TAK875), a G protein-coupled receptor 40 agonist, in Japanese patients with type 2 diabetes inadequately controlled by diet and exercise: a randomized, double-blind, placebo-controlled, phase III trial. Diabetes Obes. Metab. 17 (2015) 675-681.

[7] T. Yamashima, Dual effect of the non-esterified fatty acid receptor 'GPR40' for human health. Prog. Lipid Res. 58 (2015) 40-50.

[8] Z. Weng, K. Wang, H. Li, Q. Shi, A comprehensive study of the association between drug hepatotoxicity and daily dose, liver metabolism, and lipophilicity using 975 oral medications. Oncotarget 6 (2015) 17013-17038.

[9] A.D. Mancini, V. Poitout, GPR40 agonists for the treatment of type 2 diabetes: life after ‘TAKing’ a hit. Diabetes Obes. Metab. 17 (2015) 622-629.

[10] A. Ichimura, A. Hirasawa, T. Hara, G. Tsugimoto, Free fatty acid receptors act as nutrient sensors to regulate energy homeostasis. Prostaglandins Other Lipid Mediat. 89 (2009) 82-88. 
[11] I. Zahanich, I. Kondratov, V. Naumchyk, Y. Kheylik, M. Platonov, S. Zozulya, M. Krasavin, Phenoxymethyl 1,3-oxazoles and 1,2,4-oxadiazoles as potent and selective agonists of free fatty acid receptor 1 (GPR40). Bioorg. Med. Chem. Lett. 25 (2015) 3105-3111.

[12] J. Liu, Y. Wang, Z. Ma, M. Schmitt, L. Zhu, S.P. Brown, P.J. Dransfield, Y. Sun, R. Sharma, Q. Guo, R. Zhuang, J. Zhang, J. Luo, G.R. Tonn, S. Wong, G. Swaminath, J.C. Medina, D.C.-H. Lin, J.B. Houze, Optimization of GPR40 Agonists for Type 2 Diabetes. ACS Med. Chem. Lett. 5 (2014) 517-521.

[13] X. Du, P.J. Dransfield, D.C.-H. Lin, S. Wong, Y. Wang, Z. Wang, T. Kohn, M. Yu, S.P. Brown, M. Vimolratana, L. Zhu, A.-R. Li, Y. Su, X. Jiao, J. Liu, G. Swaminath, T. Tran, J. Luo, R. Zhuang, J. Zhang, Q. Guo, F. Li, R. Connors, J.C. Medina, J.B. Houze, Improving the Pharmacokinetics of GPR40/FFA1 Full Agonists. ACS Med. Chem. Lett. 5 (2014) 384-389.

[14] (a) M. Krasavin, A. Lukin, N. Zhurilo, A. Kovalenko, I. Zahanich, S. Zozulya, Novel agonists of free fatty acid receptor 1 (GPR40) based on 3-(1,3,4-thiadiazol-2-yl)propanoic acid scaffold. J. Enz. Inh. Med. Chem. 31 (2016) 1404-1410; (b) M. Krasavin, A. Lukin, N. Zhurilo, A. Kovalenko, I. Zahanich, S. Zozulya, D. Moore, I.G. Tikhonova, Novel free fatty acid receptor 1 (GPR40) agonists based on 1,3,4-thiadiazole-2-carboxamide scaffold. Bioorg. Med. Chem. 24 (2016) 29542963.

[15] A. Lukin, D. Bagnyukova, N. Kalichenkova, N. Zhurilo, M. Krasavin, Spirocyclic Amino Alcohol Building Blocks Prepared via a Prins-Type Cyclization in Aqueous Sulfuric Acid. Tetrahedron Lett. 57 (2016) 3311-3314.

[16] Y. Zheng, C.M. Tice, S.B. Singh, The use of spirocyclic scaffolds in drug discovery. Bioorg. Med. Chem. Lett. 24 (2014) 3673-3682.

[17] M. Krasavin, A. Lukin, D. Bagnyukova, N. Zhurilo, I. Zahanich, S. Zozulya, J. Ihalainen, M. M. Forsberg, M. Lehtonen, J. Rautio, D. Moore, I.G. Tikhonova, Free fatty acid receptor 1 (GPR40) agonists containing spirocyclic periphery inspired by LY2881835. Bioorg. Med. Chem. 24 (2016) 5481-5494.

[18] M. Krasavin, A. Lukin, D. Bagnyukova, N. Zhurilo, I. Zahanich, S. Zozulya, Novel FFA1 (GPR40) agonists containing spirocyclic periphery: polar azine periphery as a driver of potency. J. Enzyme Inhib. Med. Chem. (2016) in press (DOI: 10.1080/14756366.2016.1230110). 
[19] M. Krasavin, A. Lukin, N. Zhurilo, D. Bagnyukova, Gram-scale Synthesis of a Novel Core Building Block for the New GPR40 Agonist Design. Lett. Org. Chem. (2016) in press (DOI $10.2174 / 1570178613666160805115331)$.

[20] C.P. Briscoe, A.J. Peat, S.C. McKeown, D.F. Corbett, A. S. Goetz, T.R. Littleton, D.C. McCoy, T.P. Kenakin, J.L. Andrews, C. Ammala, J. A. Fornwald, D.M. Ignar, S. Jenkinson, Pharmacological regulation of insulin secretion in MIN6 cells through the fatty acid receptor GPR40: identification of agonist and antagonist small molecules. Br. J. Pharmacol. 148 (2006) 619-628.

[21] Calculated using online tools found at www.molinspiration.com.

[22] J.A. Brown, S.M. Goldsworthy, A.A. Barnes, M.M. Ellert, L. Tcheang, D. Daniels, A.I. Muir, M.J. Wogglesworth, I. Kinghorn, N.J. Fraser, N.B. Pike, J.C. Sturn, K.M. Steplewski, P.R. Murdoch, J.C. Holder, F.H. Marshall, P.G. Szekeres, S. Wilson, D.M. Ignar, M.S. Foord, A. Wise, S.J. Dowell, The Orphan G Protein-coupled Receptors GPR41 and GPR43 Are Activated by Propionate and Other Short Chain Carboxylic Acids, J. Biol. Chem. 278 (2003) 11312-11319.

[23] A. Hirasawa, K. Tsumaya, T. Awaji, S. Katsuma, T. Adachi, M. Yamada, Y. Sugimoto, S. Miyazaki, G. Tsujimoto, Free fatty acids regulate gut incretin glucagon-like peptide-1 secretion through GPR120, Nat. Med. 11 (2005) 90-94.

[24] J.A. Ballesteros, H. Weinsten, Analysis and refinement of criteria for predicting the structure and relative orientations of transmembranal helical domains, Biophys. J. 62 (1992) 107-109.

[25] E.G. Hohenstein, C.D. Sherrill, Effects of Heteroatoms On Aromatic $\pi-\pi$ Interactions: Benzene-Pyridine and Pyridine Dimer, J. Phys. Chem. A 113 (2009) 878-886.

[26] Current Protocols in Pharmacology; J.R. Hill, Ed.; Wiley Interscience 2003; pp 7.8.1-7.8.11. [27] A. Srivastava, J. Yano, Y. Hirozane, G. Kefala, F. Gruswitz, G. Snell, W. Lane, A. Ivetac, K. Aertgeerts, J. Nguyen, A. Jennings, K. Okada, High-resolution structure of the human GPR40 receptor bound to allosteric agonist TAK-875, Nature 513 (2014) 124-129.

[28] Schrödinger, Maestro version 10.5, LLC, New York, NY, 2016.

[29] I.G. Tikhonova, E. Poerio, Free fatty acid receptors: structural models and elucidation of ligand binding interactions, BMC Struct. Biol. 15 (2015) 16.

[30] Schrödinger, Macromodel version 11.1, LLC, New York, NY, 2016. 
[31] Schrödinger, Ligprep version 3.7, LLC, New York, NY, 2016.

[32] R.A. Friesner, J.L. Banks, R.B. Murphy, T.A. Halgren, J.J. Klicic, D.T. Mainz, M.P. Repasky, E.H. Knoll, M. Shelley, J.K. Perry, D.E. Shaw, P. Francis, P.S. Shenkin, Glide: A New Approach for Rapid, Accurate Docking and Scoring. 1. Method and Assessment of Docking Accuracy, J. Med. Chem. 47 (2004) 1739-1749. 